\title{
PV performance modelling: A review in the light of quality assurance for large PV plants
}

\author{
I. de la Parra , M. Muñoz , E. Lorenzo , M. García , J. Marcos , F. Martínez-Moreno
}

\begin{abstract}
A B S T R A C T
The quality assurance procedures associated with the financing of large PV plants are becoming increasingly more relevant to the PV scene in general. In this context, PV performance modelling is required in order to predict the energy yield and to rate the operating plant performance. Despite the availability of PV performance models since the early days of photovoltaics, the emergence of new proposals and the current debate on the development of an energy rating standard means that this can still be considered an open question. In the specific context of Quality Assurance Procedures, PV performance models must not only be accurate but must also be based on features specifically supported by manufacturers (datasheet information), in order to maintain the chain of responsibility in the event of failure. This paper reviews the currently available PV performance models with regard to accuracy and also compliance with datasheet specifications and guarantees. Accuracy is assessed through a meticulous measurement campaign conducted on PV arrays of four different technologies at a PV plant located in Navarra (northern Spain). The models reviewed are classified into physical models, based on the full I-V curve, and empirical models, which are solely based on the maximum power point (MPP). Despite the fact that physical models and MPP models with more than three parameters are currently widely used, this paper shows that empirical models with just three independent parameters suffice to accurately describe the relationship between PV array performance and operating conditions and are more easily derived from standard datasheet information. This result suggests that 3-parameter empirical models are the best option for PV performance modelling in the context of technical quality assurance procedures.
\end{abstract}

\section{Introduction}

The increasing number of large PV plants worldwide has made the specific context of the associated Quality Assurance Procedures increasingly relevant to the PV scene in general. This is due to the fact that, to a large extent, the financing of these PV plants, and return on investment, depends on these procedures. PV performance models are required here in order to predict the energy yield and to rate the operating plant performance, which basically requires comparing observed energy yields with reference values calculated from $G$ and $T_{\mathrm{C}}$ records. This framework usually entails the endorsement of responsibilities in the event of failure. Typically, the EPC (Engineering, Procurement and Construction) is liable to the owner whilst the PV module manufacturer is liable to the EPC. Hence, in order to maintain the responsibility chain, PV performance models must not only be accurate but must also be based on features specifically supported by manufacturers. In other words, as far as possible, they must comply with information given in the datasheets and, preferably, specifically covered by formal guarantees.

Modelling the maximum output power of a PV generator as a function of the operating conditions requires solving the function given by Eq. (1)

$\mathbf{P}_{\mathrm{MPM}}=\mathrm{P}_{\mathrm{MPM}}\left(G, T_{C}\right)$

Where $P_{\mathrm{MPM}}$ is the output power of the PV generator at the maximum power point and $G$ and $T_{\mathrm{C}}$ represent the operating conditions, i.e., the in-plane effective irradiance and the PV module temperature. This response is sometimes termed "performance surface" [1]. It is worth noting that the particular point of this surface corresponding to the so called Standard Test Conditions, STC (irradiance $=1000 \mathrm{~W} / \mathrm{m}^{2}$; spectrum AM1.5; cell temperature $=25^{\circ} \mathrm{C}$ ) is simply the rated power of the PV generator. From now onwards, an asterisk* will be used to refer to parameters measured under these conditions. Hence, $P^{*}{ }_{\mathrm{MPP}}=$ $P_{\mathrm{MPP}}\left(G^{*}, T_{\mathrm{C}}{ }^{*}\right)$ and power, efficiency, irradiance and temperature values will be related to STC as shown in Eq. (2): 
$p^{\prime}=\frac{P_{M P P}}{P_{M P P}^{*}} ; \eta^{\prime}=\frac{\eta}{\eta^{*}} ; G^{\prime}=\frac{G}{G^{*}}$ and $T^{\prime}=T_{C}-T_{C}^{*}$

Despite the availability of PV performance models since the early days of photovoltaics [2], it can still be considered an open question, as supported by the extensive literature disclosed by corresponding reviews [3-5], by the withdrawal of new proposals and by the current open debate on the development of an energy rating standard. PV performance models are traditionally classified as either "physical", based on the Shockley and Queisser diode equation, or "empirical", based on fitting certain predetermined equations to measured efficiency values.

This paper is primarily focused on reviewing models for performance surface construction with regard to accuracy and to compliance with datasheets and guarantees. Accuracy is assessed through a meticulous measurement campaign with four different current commercial PV technologies: $\mathrm{c}-\mathrm{Si}, \mathrm{CdTe}, \mathrm{CIGS}$ and a-Si/ $\mu \mathrm{Si}$. Five PV arrays (two are a-Si/ $\mu \mathrm{Si}$, from different manufactures), each with $P^{*}$ around $2 \mathrm{~kW}$, were connected to the grid in southern Navarra (Spain) and kept in routine operation in the course of five years. Measured power and energy production values were compared with modelled ones from different sets of equations. On the other hand, compliance with datasheets is assessed by discussing the possibility of extracting the input data required for each model with current datasheet content. Particular attention is given to crystalline silicon, which is by far the dominant technology in the current and near future markets.

Apart from the PV generator components, when modelling the output of entire PV systems, other components (DC/AC inverters, transformers, etc.), and somewhat abnormal situations (shading, inverter saturation, power curtailment and so on) also need to be addressed. However, these issues typically entail low uncertainty and are therefore disregarded in this work.

\section{A review of the PV modelling alternatives}

\subsection{Physical or full $I-V$ curve models}

A PV generator is traditionally represented by an equivalent circuit referred to as the five-parameter one-diode model (Fig. 1a). It comprises a current source, an anti-parallel diode and two resistors. Based on the Shockley and Queisser diode equation, the corresponding mathematical model is given by Eq. (3):

$I=I_{L}-I_{0}\left[\exp \left(\frac{V+I R_{S}}{V_{t}}\right)-1\right]-\frac{V+I R_{S}}{R_{S H}}$

where the 5 parameters are: photocurrent, $I_{\mathrm{L}}$; diode saturation current, $I_{0}$; thermal voltage, $V_{\mathrm{t}}$; series resistance, $R_{\mathrm{S}}$; and shunt resistance, $R_{\mathrm{SH}}$. Good descriptions of this model are available from the early days of photovoltaics [2] and are easily found in basic text books [6-9]. The thermal voltage is given by Eq. (4):

$V_{t}=m N_{C S} k T_{C} / q$

where $m$ is the so-called ideality factor, $N_{\mathrm{CS}}$ the number of solar cells associated in series, $k$ is the Boltzmann's constant $-1.381 \times 10^{-23} \mathrm{~J} /{ }^{\circ} \mathrm{K}-$ and $q$ is the absolute value of the charge on an electron $-1.602 \times 10^{-19} \mathrm{C}$-. $T_{\mathrm{C}}$ is expressed as an absolute temperature (K).

The corresponding output I-V curve used to be characterized by values at three points: short-circuit current, $I_{\mathrm{SC}}$; open-circuit voltage, $V_{\mathrm{OC}}$; and the current and voltage maximum power point, $I_{\mathrm{MPP}}$ and $V_{\text {MPP }}$, respectively (Fig. 1b). Dealing in practice with this model requires solving three different problems:

- Extraction of the parameters at STC from available information

- Extension of the parameters to other than STC values

- Solving the equation for the MPP value.

\subsubsection{Extraction of parameters at $S T C$}

In principle, in order to determine 5 parameters, 5 independent data items are required. The PV module datasheet shall be assumed to provide the three characteristic points at STC and the open-circuit voltage coefficient, $\beta$ (Datasheet content is discussed in Section 3.1.1). Then, the first three data items are obtained by writing Eq. (3) for $I_{S C}^{*}$, for $V_{O C}^{*}$ and for $\left(I_{M P P}^{*}\right.$, for $\left.V_{M P P}^{*}\right)$. A fourth equation is obtained for imposing the derivative of power at the MPP point as zero and the fifth equation is derived from the open circuit temperature coefficient concept [10]. Details of the equations are given in Annex 1.

The resulting 5 equations form an implicit and non-linear equation system which requires numerical methods demanding extensive computation and also good initial guesses for the iterations to converge. Powerful mathematical tools such as the engineering equation solver (EES) from F-Chart [10] or Lambert functions [11,12] are required. Modified formulations of Eq. (3) have been proposed with the aim of improving convergence [13-15]. Several simulations have been made with the F-solve (MATLAB), obtaining reasonable results for $\mathrm{c}-\mathrm{Si}$ when using $m=1.06$ and particular $R_{\mathrm{S}}$ and $R_{\mathrm{SH}}$ values [16] as initial guesses. However, convergence problems often needed to be addressed.

Such difficulties suggest that the direct extraction of the 5 parameters solely from datasheet information is definitively not a way to develop practical tools for energy yield prediction. Moreover, this way is made even worse by the limited representativeness of the $\left(I_{S C}^{*}, V_{O C}^{*}\right.$, $I_{M P P}^{*}, V_{M P P}^{*}$ ) set of values given on data sheets, due to corresponding module-to-module variations observed among industrial batches of a same module type, as shown in Section 3.1.1.

Sound assumptions for lessening the task of extracting parameters have been extensively explored. For example, disregarding the shortcircuit recombination current [17], i.e. Eq. (5):

$I_{L}^{*}=I_{S C}^{*}\left(1+\frac{R_{S}^{*}}{R_{P}^{*}}\right)$

Also, assuming the above equation, a value for $m$ and iterating on $R_{\mathrm{S}}$ and $R_{\mathrm{P}}$ until finding the only pair $\left(R_{\mathrm{S}}, R_{\mathrm{P}}\right)$ that guarantees only $P_{M P P}^{*}$, but not $I_{M P P}^{*}$ and $V_{M P P}^{*}$ independently [18]. Widely referred to relationships derive from comparing the fill factor $F F^{*}$ with the fill factor of an ideal cell (a cell with $R_{\mathrm{S}}{ }^{*}$ zero and $R_{\mathrm{SH}}{ }^{*}$ infinite), $F F_{0}$, using available semi-empirical expressions for the MPP [7]. The following equations Eqs. (6)-(8) apply:

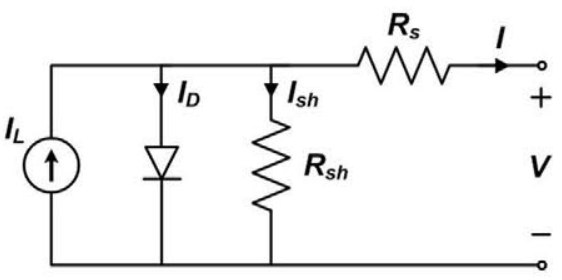

(a)



(b)

Fig. 1. a) Single diode model b) Characteristic points of the IV curve. 
$v_{O C}^{*}=\frac{V_{O C}^{*}}{V_{t}^{*}} r_{S H}^{*}=R_{S H}^{*} \frac{I_{S C}^{*}}{V_{O C}^{*}} r_{S}^{*}=R_{S}^{*} \frac{I_{S C}^{*}}{V_{O C}^{*}}$

$F F_{0}^{*}=\frac{v_{O C}^{*}-\ln \left(v_{O C}^{*}-0.72\right)}{v_{O C}^{*}+1}$

$F F^{*}=F F_{0}^{*}\left(1-r_{S}^{*}\right)\left\{1-\left(\frac{v_{O C}^{*}+0.7}{v_{O C}^{*}}\right)\left[\frac{F F_{0}^{*}\left(1-r_{S}^{*}\right)}{r_{S H}^{*}}\right]\right\}$

These equations are valid for cells of reasonable efficiency $\left(v_{\mathrm{OC}}>\right.$ 10 ), as is the case for most commercial cells today, and they become particularly useful when, again, the considered input is only $P_{M P P}^{*}$, but not $I_{M P P}^{*}$ and $V_{M P P}^{*}$ independently. Combined with reasonably choices for $m$ and $R_{\mathrm{SH}}$, these equations make the I-V curve calculation sequence fully analytical and straightforward. For example, $1.1 \leq m \leq 1.3$ and $R_{\mathrm{SH}}{ }^{*}$ greater than 5 times $V_{\mathrm{M}}{ }^{*} /\left(I_{\mathrm{SC}}{ }^{*}-I_{\mathrm{M}}{ }^{*}\right)$ represent reasonable ranges for crystalline silicon. A further simplification of this approach is considering $R_{\mathrm{SH}}{ }^{*}$ as infinite. Then Eq. (9) applies:

$R_{S}^{*}=\left(1-\frac{F F^{*}}{F F_{0}^{*}}\right) \frac{V_{O C}^{*}}{I_{S C}^{*}} I_{L}^{*} \approx I_{S C}^{*}$ and $I_{0}^{*}=I_{S C}^{*} \exp \left(-\frac{V_{O C}^{*}}{V_{t}^{*}}\right)$

In general, the equivalent circuit for the PV generator can be simplified by assuming $R_{\mathrm{SH}}{ }^{*}$ as infinite, , resulting in the so-called "4parameter model". This is extensively used for crystalline silicon modules operating in sunny places $[9,11,19-24]$, because it represents a good compromise between accuracy and complexity. Interestingly, even the "3-parameter model" resulting from the ideal cell, where effects of series and parallel resistors are disregarded, leads to reasonably good results, showing $P_{\mathrm{DC}}$ errors below $4 \%$ for a large range of $G$ and $T_{\mathrm{C}}[25-27]$.

A very different approach consists in extracting the 5 parameters from a measured I-V curve (instead of datasheet values). The literature contains many different variations for this question [12,23,28-45]. Typically, a key step consists in taking $R_{S H}$ as the inverse of the slope around short-circuit point as is shown in Eq. (10):

$\left.\frac{d I}{d V}\right|_{I S C}=-\frac{1}{R_{S H}}$

This approach has been adopted by widely-known software such as PVsyst [46] or the CECPV calculator [47]. Such software is userfriendly and has many supporters. However, due to the fact that the I-V curves are obtained from independent testing on a single PV module sample, objections regarding representativeness and also PV manufacturer commitment can arise when predicting energy yield in a contractual context.

\subsubsection{Extension of parameters to arbitrary operating conditions}

Most typically, $I_{\mathrm{L}}$ is assumed to be almost linearly related to irradiance i.e. Eq. (11):

$I_{L}=I_{L}^{*} G^{\prime}\left[1+\alpha T^{\prime}\right]$

Where $\alpha$ is the temperature coefficient for the short-circuit current. This value can be found on data sheets and is about one order of magnitude lower than $\beta$, so that it can be disregarded with no significant error. The diode saturation current is given by Eq. (12) [48]

$I_{0}=I_{0}^{*}\left(\frac{T_{C}}{T_{C}^{*}}\right)^{3} \exp \left[\frac{E_{g}}{k}\left(\frac{1}{T_{C}^{*}}-\frac{1}{T_{C}}\right)\right]$

where $E_{\mathrm{g}}$ is the material energy band gap $(1.121 \mathrm{eV}$ for crystalline silicon). $E_{\mathrm{g}}$ exhibits a small temperature dependence that can be described by Eq. (13) [10]

$\frac{E_{g}}{E_{g}^{*}}=1-0.0002677 T^{\prime}$ $m$ and $R_{\mathrm{S}}$ are generally assumed to be constant, while $R_{\mathrm{SH}}$ appears to increase with decreasing irradiance. Inverse [10] and Exponential [49] empirical relationships have been proposed to describe this effect, respectively Eq. (14):

$R_{S H}=\frac{R_{S H}^{*}}{G^{\prime}}$

and Eq. (15)

$R_{S H}=R_{S H}^{*}+\left(R_{S H 0}-R_{S H}^{*}\right) \exp \left(-c_{R S H} G^{\prime}\right)$

where the shunt resistance at no irradiance, $R_{\mathrm{SHO}}$, and the exponential coefficient $c_{\mathrm{RSH}}$ are empirically adjusted. The observed ratio $R_{\mathrm{SHO}} /$ $R_{\mathrm{SH}}{ }^{*}$ ranges from 4 for crystalline silicon to 12 for triple junction amorphous. $c_{\mathrm{RSH}}$ ranges from 2 (CdTe) to 5.5 for $\mathrm{Si}$.

It must be noted that the power temperature coefficient is a result and not a data input for these procedures. In fact, if it is necessary to strictly comply with the data sheet, then the resulting $\gamma$ can be fitted to a predetermined value by adding an adjusting exponent to Eq. (12), but this is at the cost of significantly increasing the calculation complexity. On similar lines, an alternative equation for $I_{0}$, based on the temperature coefficient of voltage data, is obtained by writing Eq. (3) for $V_{\mathrm{OC}}$ and imposing the value as Eq. (16)

$V_{O C}=V_{O C}^{*}\left[1-\beta T^{\prime}\right]+V_{t} \ln G^{\prime}$

Finally, considering additional dependences of $I_{0}$ on irradiance and of $R_{\mathrm{S}}$ on temperature by means of Eq. (17)

$I_{0}=I_{0}^{*} G^{\prime \tau}\left(\frac{T_{C}}{T_{C}^{*}}\right)^{3} \exp \left[\frac{E_{g}}{k}\left(\frac{1}{T_{C}^{*}}-\frac{1}{T_{C}}\right)\right]$

and Eq. (18)

$R_{S}=R_{S}^{*} \exp \left[\delta T^{\prime}\right]$

where $\tau$ and $\delta$ are empirical parameters that need to be adjusted with other than STC information, has also been proposed [50,51]. Another empirical and simpler dependence of $R_{s}$ on temperature has also been proposed by [52]. Obviously, adding empirical parameters potentially improves the model accuracy for reproducing the observed performance of an individual PV module. However, yet again, due to the module-to-module variations among the same batch of industrial PV modules, the representativeness of such a procedure is questionable and, therefore, so is the benefit of adding these two parameters to yield prediction exercises.

\subsubsection{Solving the model for MPP value}

Eq. (3) is implicit and non-linear and is usually solved by iterative methods (Newton-Raphson, etc.). Ruiz has developed an analytical procedure, based on the Taylor series of the first Newton-Raphson step, which is easy to apply. Although not yet published in peer reviewed journals, it has been extensively used at the IES-UPM and gives excellent results in terms of accuracy, which justifies including the corresponding equations in Annex 1.

Table 1 contains a list of a variety of $\mathrm{I}-\mathrm{V}$ curve models proposed in the literature.

\subsection{Empirical or MPP models}

These are empirical descriptions of observed maximum power values in relation to the corresponding operating conditions. The simplest MPP model consists in assuming just a linear relationship between power and irradiance. That is Eq. (19):

$p^{\prime}=G^{\prime}$ or $\eta^{\prime}=$ constant

However, the constancy of efficiency throughout the entire range of operating conditions is hardly realistic. A first refinement consists in 
Table 1

Different I-V curve models found in the available literature.

\begin{tabular}{|c|c|c|c|c|c|c|c|c|c|}
\hline \multicolumn{10}{|c|}{ I-V curve models } \\
\hline \multicolumn{10}{|c|}{$I=I_{L}-I_{0}\left[\exp \left(\frac{V+I R_{S}}{V_{7}}\right)-1\right]-\frac{V+I R_{S}}{R_{S H}}[2,6$} \\
\hline \multicolumn{6}{|c|}{ 1. Extraction of parameters at STC } & \multicolumn{3}{|c|}{ 2. Extension to arbitrary operating conditions } & $\begin{array}{l}\text { 3. Solving } \\
\text { the model } \\
\text { for MPP } \\
\text { value }\end{array}$ \\
\hline \multicolumn{5}{|c|}{ From datasheet } & $\begin{array}{l}\text { From measured } \\
\text { I-V curves }\end{array}$ & \multicolumn{3}{|c|}{$\begin{aligned} I_{L} & =I_{L}^{*} G^{\prime}\left[1+\alpha T^{\prime}\right] \\
m & =m^{*}\end{aligned}$} & $\begin{array}{l}\text { Iterative } \\
\text { methods }\end{array}$ \\
\hline $\begin{array}{l}\text { Solving } 5 \\
\quad \text { equa- } \\
\text { tion } \\
\text { system }\end{array}$ & $\begin{array}{l}\text { Making } \\
\text { assumpt } \\
I_{L}, F F, m\end{array}$ & $\begin{array}{l}\text { several } \\
\text { ions for } \\
\text { or } R_{S H}\end{array}$ & 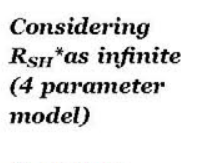 & $\begin{array}{l}\text { Considering } \\
\boldsymbol{R}_{S_{H}^{*}}=\infty \text { and } \\
\boldsymbol{R}_{S}^{*}=0(3 \\
\text { parameter } \\
\text { model })\end{array}$ & $\begin{array}{l}{[28-30,32-} \\
34,35,12,23,36- \\
43-45]\end{array}$ & $\begin{array}{l}\text { Alternative } \\
\text { expressions } \\
\text { for } I_{o}\end{array}$ & $\begin{array}{l}\text { Alternative } \\
\text { expressions } \\
\text { for } R_{S H}\end{array}$ & $\begin{array}{l}\text { Alternative } \\
\text { expressions } \\
\text { for } R_{S}\end{array}$ & $\begin{array}{l}\text { (Newton- } \\
\text { Raphson, etc.) } \\
\text { vs } \\
\text { Ruiz analytical } \\
\text { method }\end{array}$ \\
\hline$[10-13,14]$ & {$[17,18,7]$} & & $\begin{array}{l}{[9,11,19,22-} \\
24,53,54]\end{array}$ & [25-27] & & $\begin{array}{l}{[48,10]} \\
\text { vs } \\
{[50,51]}\end{array}$ & $\begin{array}{l}{[10]} \\
\text { vs } \\
{[49]}\end{array}$ & $\begin{array}{l}R_{S}=R_{S}{ }^{*} \\
\text { vs } \\
{[50,51]} \\
\text { vs } \\
{[52]}\end{array}$ & (Annex 1) \\
\hline
\end{tabular}

considering that efficiency is affected by temperature, decreasing at a constant rate, to give Eq. (20):

$\eta^{\prime}=\left(1+\gamma T^{\prime}\right)$

where $\gamma$, the power temperature coefficient, is considered to be a constant value. This value is almost always found in datasheets. This formula is well established $[55,56]$ and is still widely used.

Instead of using the lumped coefficient for power, a similar model can be written from the temperature coefficients for short-circuit current, open-circuit voltage and fill factor, $\alpha, \beta$ (always found in datasheets) and $\xi$, respectively. It is easy to deduce that Eq. (20) is equivalent to Eq. (21)

$\eta^{\prime}=\left(1+\alpha T^{\prime}\right)\left(1+\beta T^{\prime}\right) \quad\left(1+\xi T^{\prime}\right)$

and that $\gamma$ meets the following Eq. (22):

$\gamma=\alpha+\beta+\xi$

Due to the fact that, in practice, the $F F$ is much less temperature sensitive than $V_{\mathrm{OC}}$, some authors have suggested considering it as a constant, or $\xi=0$ [57].

With these models, it can be slightly complicated to also consider the irradiance-dependent efficiency. Although this was initially attempted by adding a base 10 logarithm [55], it is better implemented by a model proposed more than ten years ago $[58,59]$ and already used by a number of authors $[60,61]$. This is Eq. (23):

$\eta^{\prime}=\left(1+\gamma T^{\prime}\right)\left(a_{1}+a_{2} G^{\prime}+a_{3} \ln G^{\prime}\right)$

where $a_{1}, a_{2}$ and $a_{3}$ are empirically adjusted parameters. Due to the fact that the particularization of this equation for STC leads to condition given by Eq. (24)

$a_{1}+a_{2}=1$

they can be determined from just two values of the relationship between efficiency and irradiance. Datasheets often give only the value for $200 \mathrm{~W} / \mathrm{m}^{2}, \eta^{\prime}(0.2)$. It is worth noting that efficiency increases with decreasing irradiance, due to series resistance, represented by the term $a_{2} \cdot G$, giving $a_{2} \leq 0$, while efficiency decreases with decreasing irradiance, due to shunt resistance, represented by term $a_{3} \cdot \ln G^{\prime}$, giving $a_{3}$ $\geq 0$. Therefore, a conservative approximation solely based on this value assumes the following Eq. (25)

$a_{1}=1 ; a_{2}=0 ; a_{3}=\frac{\eta^{\prime}(0.2)-1}{\ln 0.2}$
However, this must be treated with caution, given the fact that, when c-Si and sunny places are concerned, the positive effect of series resistance can even overcome the negative effect of shunt resistance. Another practical possibility to address this difficulty consists in granting generality to already published values for particular modules. The JRC of ISPRA has published efficiency values at different irradiances for a number of technologies [62]. By way of example, for a poly-Si module they give $\eta^{\prime}(0.6)=1$ and $\eta^{\prime}(0.2)=0,96$, which leads to $a_{1}=1,184, a_{2}=-0184$ and $a_{3}=0118$.

Table 2 contains a chronological list of a variety of MPP models proposed since the mid nineteen-nineties Eqs. (26)-(37). Note that the models differ with regard to the number of empirical parameters involved, ranging from just two - Eqs. (26) and (28) - up to six - Eqs. (31) and (36). The justification for proposals often includes the improvement of accuracy, mainly for Thin Films and low irradiance, and also to deal with the logarithm in the event that $G=0$. However, it is surprisingly disturbing to note that comparisons with previous model proposals are virtually absent in the publications describing most of these models (many models have only been presented at Conferences, but not in peer-reviewed journals). Interestingly, round-robins of different energy prediction methods based on some of these models - in particular, equations $[29,30]$ and [33]-, within the European projects "PV-Catapult" and "Performance", dealing with setting standards for the PV industry, have concluded that "-all methods were able to predict the energy production of known modules in different environments very well" [63] and "All energy prediction methods showed similar results, which does not allow for any preferred selection" [64].

An immediate idea arising from these comparisons is that only three independent parameters, one for temperature and two for irradiance, suffice to accurately describe the PV performance of PV modules in relative terms to STC. Note that not all the parameters included in the equations in Table 2 are independent. For example, Eq. (23) includes 3 parameters for irradiance but these are not independent, as they must comply with Eq. (24).

It follows that there is little or no justification for the use of more complex models, something that comes as a surprise to many people: "Surprisingly, there doesn't seem to be a need for overly complicated modelling to achieve this accuracy for most technologies" as stated in the final brochure of the aforementioned Performance European [65] and can help to explain why proposals based on more than three parameters are getting very limited success. It must be understood that increasing the 
Table 2

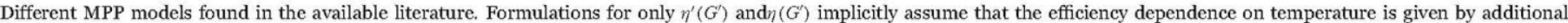
factor $\left(1+\gamma T^{\prime}\right)$. All the letters other than $\mathrm{G}, \mathrm{T}$ and $\mathrm{P}$ represent empirically adjusted, non-dimensional parameters.

\begin{tabular}{ll}
\hline Ref. & Formulation \\
\hline (Evans [55]) & $\eta^{\prime}\left(G^{\prime}, T^{\prime}\right)=1+a_{1} T^{\prime}+a_{2} l g_{10} G^{\prime}$ \\
(Taylor [84]) & $\eta^{\prime}\left(G^{\prime}, T^{\prime}\right)=A+B G^{\prime}+C T^{\prime}$ \\
(Randall [58]) & $\eta^{\prime}\left(G^{\prime}\right)=1+a \cdot \ln G^{\prime}$ \\
(Willians [59]) & $\eta^{\prime}\left(G^{\prime}\right)=a_{1}+a_{2} G^{\prime}+a_{3} \ln G^{\prime}$ \\
(Willians [80]) & $\eta^{\prime}\left(G^{\prime}, T^{\prime}\right)=\left(1+\alpha T^{\prime}\right)\left(1+c_{0} \ln G^{\prime}+c_{1} l^{2} G^{\prime}+\beta T^{\prime}\right)$
\end{tabular}

(Rosell [85])

$$
P_{D C}\left(G_{e f f}, T_{C}\right)=D_{1} G_{e f f}+D_{2} T_{C}+D_{3}\left(\ln G_{e f f}\right)^{d 5}+D_{4} T_{C}\left(\ln G_{e f f}\right)^{d 5}
$$

(Durisch [71])

$$
\eta\left(G^{\prime}, T_{C}\right)=a\left[b G^{\prime}+\left(G^{\prime}\right)\right]\left(1+d \frac{T_{c}(o C)}{25}+e\right)
$$

(Heydenreich [86])

$$
\eta(G)=a G+b \ln (G+1)+c\left[\ln ^{2} \frac{G+e}{G+1}-1\right]
$$

(Montgareuil [87])

$$
\eta^{\prime}\left(G^{\prime}\right)=1+a\left(G^{\prime}-1\right)+b \ln G^{\prime}+c\left(G^{\prime}-1\right)^{2}+d l n^{2} G^{\prime}
$$

(Reich [61])

(Huld [83])

$$
\eta^{\prime}\left(G^{\prime}\right)=a_{1}+a_{2} G^{\prime}+a_{3} \ln \left(G^{\prime}+a_{4}\right)
$$

$$
\begin{aligned}
P_{M P P}\left(G^{\prime}, T^{\prime}\right)= & G^{\prime}\left(P_{M P P}^{*}+k_{1} \ln G^{\prime}+k_{2} \ln \left(G^{\prime}\right)\right)+k_{3} T^{\prime}+k_{4} T^{\prime} \ln G^{\prime} \\
& +k_{5} T^{\prime} \ln \left(G^{\prime}\right)+k_{6}\left(T^{\prime}\right)^{2}
\end{aligned}
$$

(Silva [88])

$$
\eta^{\prime}(G)=\left(1+b \ln G^{*}-c G^{* 1 / 2}\right)\left(1+b \ln G-c G^{1 / 2}\right)
$$

number of module parameters also increases the complexity of the measurements required to determine their values. The IEC 61853 method can serve as paradigm. It is based on first measuring the PV module performance at 23 points of a $\left(G, T_{C}\right)$ matrix, where $G$ and $T_{C}$ ranges from 100 to $1100 \mathrm{~W} / \mathrm{m}^{2}$ and 15 to $75^{\circ} \mathrm{C}$, respectively. Then, the PV module is rated at 5 different conditions, called High Temperature Conditions, HTC $\left(1000 \mathrm{~W} / \mathrm{m}^{2}, 75^{\circ} \mathrm{C}\right)$; Standard Test Conditions, STC $\left(1000 \mathrm{~W} / \mathrm{m}^{2}\right.$, $\left.25^{\circ} \mathrm{C}\right)$; Nominal Operating Cell Temperature, NOCT $\left(800 \mathrm{~W} / \mathrm{m}^{2}\right.$, $\left.T_{\text {ambient }}=75^{\circ} \mathrm{C}\right)$, Low Temperature Conditions $\left(500 \mathrm{~W} / \mathrm{m}^{2}, 15^{\circ} \mathrm{C}\right)$ and Low Irradiance Conditions, LIC $\left(200 \mathrm{~W} / \mathrm{m}^{2}, 25^{\circ} \mathrm{C}\right)$. Finally, the MPP for a particular $\left(G, T_{C}\right)$ pair is calculated by interpolations of these conditions. Despite the fact that the first draft of IEC 61853 was published in 2001 and that it was explicitly recommended by organizations as important as the Solar American Board for Codes and Standards [66], this standard has still never been implemented in practice. Interestingly, the authors of a detailed validation of the complete IEC 618532 methodology conclude: "The authors feeling is that the complexity of the standard is actually not beneficial for an accurate energy prediction, as it requires data which is actually normally not known and the generation of this... seems to affect the overall agreement more than it would be without this complicated step" [67]. A similar opinion is expressed by the authors of a comparison between the IEC 618523 methodology and Eq. (30): "The two methodologies were found to have comparable accuracy...it is not clear whether the gain in accuracy would justify the cost in complexity of measurements and calculations involved" [68]. On the same lines, a recent Fraunhofer ISE proposal of a method for energy rating [69] is based on the model given by Eq. (33), which is in fact based on three independent parameters. This model has been widely experimentally validated for $\mathrm{c}-\mathrm{Si}$ and TF technologies [70].

Similar comments can be extended to the Durisch model $[71,72]$ or 
the so-called "Loss Factor Model" which requires up to 15 empirical parameters to describe the performance of amorphous silicon modules [73-75] .

Similar conclusions in favour of model simplicity have followed MPP models comparisons performed at the University of Jaen (Spain). Concerning the $\mathrm{c}-\mathrm{Si}$, the conclusion has been that "... taking an overall view both, $F F_{\mathrm{K}}$ and Osterwald's models - that have 1 and 2 parameters, respectively-combine simplicity and accuracy best, so they are definitively recommended for PV engineering in Mediterranean climates “ [57]. And this conclusion was later extended to thin films, following a testing campaign with four different technologies a-Si, CIGS, CdTe and a-Si:H/ $\mu \mathrm{Si}: \mathrm{H})$ in Jaen, Madrid and Barcelona) [76].

Finally, it is interesting to mention that some models have been implemented in popular, open-access energy-prediction tools. The so-called SANDIA or King's model [77,78] has been implemented in the Solar Advisor Model, developed by NREL [79]. The original version of this model uses broadband irradiance as input and includes a number of equations and many coefficients to cope with spectral and angular responses. However, this is not necessary when using effective irradiance as input and the model can be substantially simplified. This model determines the performance surface by means of empirical equations for both the current and voltage at the maximum power point. Their combination leads to the four parameters Eq. (30) for the relative efficiency [80]. This equation was implemented in the PVGIS (developed by the European JRC [81]) interactive web applications for the estimation of PV production, using empirical values obtained from measurements of a single c-Si module: $\alpha=1.2 \times 10^{-3}{ }^{\circ} \mathrm{C}^{-1} ; \beta=-4.6 \times 10^{-3}{ }^{\circ} \mathrm{C}^{-1} ; c_{0}=0.033$ and $c_{2}=-0.0092$ [82]. It was later substituted by the slightly more complex possibility given by Eq. (36) [83]. Coefficients for 18 crystalline PV modules were obtained by means of an extensive measurement campaign (at least 24 power values at corresponding ( $\left.G_{\text {eff, }}, T_{\mathrm{C}}\right)$ pairs were measured for each module), and the results were combined to generate a model for a generic crystalline silicon module that was included in the online PV estimator in PVGIS. It is given by $k_{1}=-0.01724 ; \quad k_{2}=-0.04047 ; \quad k_{3}=-0.0047^{\circ} \mathrm{C}^{-1} ; k_{4}=1.49 \times 10^{-4}{ }^{\circ} \mathrm{C}^{-1}$; $k_{5}=1.47 \times 10^{-4}{ }^{\circ} \mathrm{C}^{-1}$ and $k_{6}=5 \times 10^{-6}{ }^{\circ} \mathrm{C}^{-2}$. Yordanov [52] proposed a set of equations that makes it possible to obtain parameters $k_{1}$ to $k_{6}$ from the I-V curve parameters.

\subsection{The case of thin-film technologies}

Modelling the performance of thin-film technologies is a slightly more complex issue than modelling that of crystalline silicon. The case of a-Si modules is probably the best example. These modules are subjected to the Staebler-Wronski effect [89], which provokes a decrease in performance upon exposure to light, typically reducing efficiency by $15-20 \%[90,91]$ compared with its initial value. Additionally, after reaching stabilization (about 6 months of outdoor exposure), the efficiency of this material exhibits seasonal variations [92] that have been attributed to mainly two effects: spectral effects [93-96], and thermal annealing [97,98]. These seasonal changes can be described very closely with the sinusoidal function [99] which is given by Eq. (38):

$\frac{\eta(t)}{\eta^{*}}=A \sin \left(2 \pi \frac{t}{T}+\varphi\right)+\eta_{A V}$

where $A$ is the amplitude, $t$ is the time (month) for which the efficiency is to be predicted, $T$ is the total time period (12 months), $\varphi$ is the phase and $\eta_{A V}$ is the average efficiency.

The spectral effects on the performance of the different PV technologies (mainly on a-Si) have been widely discussed in the literature [94103]. The published studies point out that disregarding the spectral effects could lead to noticeable errors in annual energy calculations in the case of
a-Si (from $1.5 \%$ up to $10 \%$ ) $[100,103]$ but this is less important in HIT, CIGS and c-Si (less than 1.5\%) [102]. The spectral impact on the annual energy for CdTe used to be less than on a-Si but larger than on $\mathrm{c}-\mathrm{Si}$ modules. [104]. In order to model the spectral influence on the performance of the different PV technologies, some authors use parameters such as the Average Photon Energy [105] or the Useful Fraction [100] to characterize the spectral distribution of incident irradiance and its correlation with the PV module efficiency. However, this procedure requires the use of spectroradiometers, which are not commonly used as measurement instruments. Other authors suggest correlating the PV modules efficiency with the air mass, $A M[78,101]$, or with both the $A M$ and the clearness index, $K_{T}$ [106]. In these papers, empirical correlations have been proposed for a selection of modules of the different PV technologies, except for CIGS. Nevertheless, it has been pointed out [104] that the spectral behaviour differs not only among different technologies under real outdoor conditions, but also significantly within a single technology. For this reason, most of these empirical correlations do not have a general validity. In this context, because no detailed spectral response data are commonly available for each PV module, and also because spectral distribution of incident irradiance is difficult to obtain, this paper postulates two generalizations:

- CdTe and $\mathrm{CI}(\mathrm{G}) \mathrm{S}$ perform similar to c-Si.

- a-Si/ $\mu \mathrm{c}-\mathrm{Si}$ performs similar to a-Si which, in turns, performs as described in [77] or in [106].

This makes it possible to deal with these technologies in practice, using only available information, however at the cost of increased uncertainty.

Finally, it is worth mentioning that some improvement has also been reported in Cds/CdTe PV module performance modelling if real and nonconstant temperature coefficients are used [107]. Nevertheless, empirical measurements are required and the complexity of the performance model is increased. In this paper, maintaining the criteria of using only available information, the constant temperature coefficients provided by manufacturers are used.

\subsection{I-V curve versus MPP models}

Generally speaking, the PV performance modelling panorama can be understood to have originated in two different areas, each with its own specific mandate. On the one hand, laboratories specializing in photovoltaics, specifically involved in systematic measurements on industrial PV modules, have been the main cradle of MPP models, which are essentially empirical and require relatively easy calculations. On the other hand, universities, often dealing with research and theoretical studies, have been the main cradle of full I-V models, which are essentially physical and require more complex calculations. Not surprisingly, most model comparisons available today have been made within one of these two areas. In fact, among the extensive literature disclosed by PV performance modelling reviews [3,4,108,109], only 2 papers have been found that simultaneously address energy yields predicted by MPP and IV curve models and, even so, in a rather restricted manner:

The first [110] compares the energy yield observed at three c-Si PV arrays located at Alburquerque (USA) with the predictions of three performance modelling alternatives available within the so-called Solar Advisor Model, SAM, a free software program developed by the NREL: the Sandia model given by Eq. (30), a 5-parameter 1-diode model and the simplest MPP that considers only the efficiency dependence on temperature, given by Eq. (20). The coefficients for implementing the SANDIA and 5-parameters models are taken from the database distributed with SAM (derived from particular modules measured at 
SANDIA and NREL) while the temperature coefficient for the MPPTD was taken from the manufacturer's datasheet. The PV arrays are of different power outputs $(1.1,1.11$ and $2.3 \mathrm{~kW})$ and the same module type but from two different batches (210 and 220 STC nameplate rating). The interesting results is not only that "... all the modules agree within about $2 \%$ ", but also that the differences of a same model for the three PV arrays are slightly greater than this figure. This suggests that the differences due to module-to-module variations supersede the differences due to model-to-model variations.

The second [61] analyses the low light performance of 41 commercially produced c-Si cells. Due to the fact that the work is made in the context of Product Integrated PV, that are likely to be operated most often indoors that outdoors, this work pays particular attention to the range of very low irradiances $\left(<100 \mathrm{~W} / \mathrm{m}^{2}\right.$ ). Despite the fact that this range is scarcely relevant for standard PV generators, the conclusions of the paper are still useful: the accuracy of diode models in this range can be very high but is very dependent on the parameters used (this is because $R_{\mathrm{P}}$ is of utmost importance in this range, which is not the case at normal irradiance levels); the MPP model given by Eq. (35) performs very well. Note that this equation is an adaptation of Eq. (29) by including an additional parameter in the logarithmic part, simply to avoid negative efficiencies and to improve fitting accuracy at very low light, below $1 \mathrm{~W} / \mathrm{m}^{2}$; and that cells from one and the same manufacturer show large differences in cell efficiencies at low irradiance. This helps explain that module-to-module variations also used to be large, as will be seen in section 3.1.

It has been postulated above that only three independent parameters are required to accurately describe the relationship between PV array performance and operating conditions. It follows that 5 parameters, as required by I-V models, are more than is strictly needed for energy yield calculations for PV arrays operating at MPP. Obviously, I$\mathrm{V}$ models allow for studying the performance of the PV array at points other than MPP, which may be useful for analyzing particular problems such as direct coupling to batteries or DC motors. However, it should be mentioned that the output power limitation for PV systems characterized by large array-to-inverter ratios can be easily solved without dealing with I-V curves, and that shading impacts can also be correctly evaluated without I-V curves [111].

\section{PV modelling in the context of quality assurance practices}

Technical quality assurance procedures are focused on ensuring that actual performance is in line with expectations. For a gridconnected PV plant, prior to construction, expectations are established through a forecast simulation exercise describing the expected site evolution of the operating conditions and the corresponding power response of the PV system. This makes it possible to predict the yearly energy production, of paramount importance for the economic balance and for the bankability of the PV plant. Solar radiation databases and technical specifications of the PV plant components provide input data for this exercise.

It must be noted that predicting the operating conditions unavoidably relies on the available meteorological data, and that this is far from being an exact science [112-114]. Therefore, the corresponding uncertainty is considered to be a source of risk, yet no one can be held responsible for future weather. However, the power response of PV systems is mainly a matter of technical quality and strict responsibilities that need to be endorsed by PV equipment suppliers, who obviously must agree on the corresponding technical specifications that they are requested to guarantee. It follows that the performance models must be based on features specifically supported by manufacturers.
Note that, regarding PV arrays, this applies not only to the $P_{M P P}^{*}$ value but also to the following function (Eq. (39))

$P_{M P P}=P_{M P P}\left(P_{M P P}^{*}, G, T_{C}\right)$

It is worth noting that $P_{M P P}^{*}$ can adopt two different values: the "nominal" value, $P_{M P P, N O M}^{*}$, which is the product of the number of PV modules multiplied by the corresponding nameplate STC power and the "real" value, $P_{M P P, R E A L}^{*}$, which is the power measured at the inverter input. Depending on the contractual conditions, the nominal value is sometimes substituted by the "flash" value $P_{M P P, F L}^{*}$, which is the sum of the power of all the constituent modules, as measured in the manufacturer's flash tests.

In practice, yield prediction includes the consideration of a baseline loss scenario, agreed among all the parties involved in the project (EPC, investors and independent experts) and establishing the maximum allowable difference between the performance of a hypothetical reference system, whose characteristics are extracted directly from the manufacturer's information and the actual system to be constructed. Such scenario lumps together all the losses that can be properly associated with the concept of technical quality (due to underrating, initial degradation, mismatching, wiring, etc.) and can be adequately quantified by ratio $P_{M P P, R E A L}^{*} / P_{M P P, N O M}^{*}$ (or $P_{M P P, R E A L}^{*} / P_{M P P, F L}^{*}$ ).

At a later date, once the PV plant is operating, its technical quality is typically assessed through a number of performance indices that are derived from comparing the observed energy productions with hypothetical reference values calculated from observed operating conditions. This is first done at the Commissioning Tests, over a relatively short period of a few weeks. In the past, the most widely-used index was the Performance Ratio, PR. This index, defined in IEC 61724 ("Photovoltaic system performance monitoring: guidelines for measurement, data exchange and analysis"), is calculated as Eq. (40)

$P R=\frac{E_{A C}}{P_{M P P,}^{*} \quad N O M \frac{G_{\Delta T}}{G^{*}}}$

where $E_{\mathrm{AC}}$ is the energy effectively delivered to the grid and $G_{\Delta \mathrm{T}}$ is the annual in-plane irradiation during that period. Note that this $P R$ value can be directly calculated without any kind of modelling, due to the fact that the $E_{\mathrm{AC}}, P_{M P P, N O M}^{*}$ and $G_{\triangle \mathrm{T}}$ values are directly given by the billing energy meter of the PV plant, the PV manufacturer receipt and the integration of a solar irradiance signal. However, it entails the fundamental drawback of being time dependent because it includes not only pure technical losses, considered at the baseline loss scenario, but also unavoidable losses due to efficiency variations with operating conditions, which are either time or site dependent but not related to the concept of technical quality. Thus, the rating result of a similar PV plant varies with the climatic conditions for the rating period, which seems contrary to common sense.

Such unavoidable losses need to be removed by more accurate technical assessment procedures. A nice possibility is to consider the so-called Performance Ratio at Standard Test Conditions, $P R_{\mathrm{STC}}$, given by Eq. (41):

$P R_{S T C}=\frac{P R}{\prod_{i}\left(1-\Delta E_{i}\right)}$

Where $\Delta E$ represents energy losses during the considered period and subscript "i" extends to all the unavoidable energy loss phenomena (due to operating temperature, irradiance and also to other phenomena inherent in the design such as DC/AC conversion, shading or inverter saturation). All these losses must be calculated from measured $G$ and $T_{\mathrm{C}}$ values, which obviously require some kind of modelling. It is important to realize that the coherence of the full quality assurance 
process makes it necessary to use the same PV performance model as for the energy yield forecast. Otherwise, the energy forecast baseline loss scenario is not properly verified. This need for model homogeneity has also been indicated by other authors [115]. It is worth noting that, disregarding other than PV array losses, $P R_{S T C}$ is equal to ratio $P_{M P P, R E A L}^{*} / P_{M P P, N O M}^{*}$

If $P_{M P P}$ data are available; an equivalent procedure consists in deriving corresponding $P_{M P P, R E A L}^{*}$ values, i.e., solving the inverse of Eq. (39). Then the average result for the period under consideration makes it possible to directly calculate ratio $P_{M P P, R E A L}^{*} / P_{M P P, N O M}^{*}$.

\subsection{Sources of input data}

Possible sources of input data for modelling PV performance are manufacturers' datasheets, independent measurements and operating data. Representativeness, guarantee and adequacy for model fitting deserve further comment.

\subsubsection{Manufacturers' datasheet content and module-to-module variations}

Manufacturers provide data sheets for each PV module type. According to standard EN 50380 ("Data sheet and nameplate information for photovoltaic modules") these must contain characteristic current and voltage values for three points of the I-V curve: shortcircuit, open circuit and MPP and for two different $\left(G, T_{\mathrm{C}}\right)$ conditions: $\operatorname{STC}\left(G^{*}, T_{\mathrm{C}}{ }^{*}\right)$ and NOCT $\left(800 \mathrm{~W} / \mathrm{m}^{2}, \approx 45^{\circ} \mathrm{C}\right)$; the efficiency reduction from STC to $\left(200 \mathrm{~W} / \mathrm{m}^{2}, T_{\mathrm{C}}{ }^{*}\right), \eta^{\prime}(0.2)$; the NOCT and the temperature coefficients for open circuit voltage, $\beta$, and for short-circuit current, $\alpha$. However, nowadays, this standard is far from being generally observed. Current and voltage at NOCT and low light performance values are sometimes missing [116]. In contrast, although not required by EN 50380 , all the data sheets checked include the value of the temperature coefficient for power, $\gamma$.

Nowadays, standard guarantees are restricted to the value of $P_{M P P}^{*}$ while the rest of the data sheet content is given by way of general information, but not particularly intended to support efficiency quality controls. As a result, guarantees on values other than $P_{M P P}^{*}$ must be agreed with the PV modules manufacturer, prior to the PV modules supply. The IES-UPM experience on the quality control of large PV plants, now spanning PV plants of up to around $300 \mathrm{MW}$ and mainly performed within the context of "due diligences" associated with large PV plant bank financing, includes several cases of PV manufacturers providing guarantees also on $\gamma$ values.

Datasheet representativeness is limited by module-to-module variations and essentially consistent with guarantees: PV modules are usually marketed with power tolerances of around $3 \%$ but the variability of other than $P_{M P P}^{*}$ can be significantly larger. As a representative example, observed width ranges at a flash-list of about 14000 crystalline silicon PV modules recently analyzed in our laboratory are $1.9 \%$ for $P_{M P P}^{*}, 5 \%$ for $I_{S C}^{*}, 2.6 \%$ for $V_{O C}^{*}, 5.9 \%$ for $I_{M P P}^{*}$ and $6.3 \%$ for $V_{M P P}^{*}$.

In the context of checking PV plants, the temperature coefficients and the efficiency variations versus irradiance are often tested on several examples of PV modules of the same type. Fig. 2 shows the results for a $\mathrm{c}-\mathrm{Si}$ and for a CdTe cases. Table 3 gives the values of $\gamma$ and $1-\eta^{\prime}\left(G^{\prime}\right)$ for $G^{\prime}=0.6$ and $G^{\prime}=0.2$. Note the latter represents the irradiance loss (positive values) or gains (negative values) at $G$. Corresponding datasheet information is also displayed. It is noticeable that, firstly, the temperature response is homogeneous (ranging from $-3 \%$ to $+4 \%$ around the average) and rather similar to datasheet content and, secondly, the irradiance response is largely non-homogeneous but always better than derived from the $\eta^{\prime}(0.2)$ value found on the datasheets.

It is worth mentioning that, from our experience, data sheets temperature coefficients are not always fully consistent. For example, there are two ways of deriving $P_{M P P}^{*}$ values from I-V curves measured at other than STC conditions. One consists in, firstly, extrapolating to STC the full I-V curve in accordance with IEC-6081, which use $\alpha$ and $\beta$, and, secondly, obtaining the $P_{M P P}^{*}$ value. The other consists in, firstly, obtaining the maximum power of the measured curve and, secondly, extrapolating only this value to STC, using $\gamma$. Ideally, both results should fully match. However, they usually differ by about $2-3 \%$, and our experience includes differences of up to $5 \%$.

As described above, the $5 \mathrm{i}-\mathrm{v}$ curve model parameters can, in principle, be extracted from the $I_{S C}^{*}, V_{O C}^{*}, I_{M P P}^{*}, V_{M P P}^{*}$ and $\beta$ values which are all found on datasheets. However, responsibility concerns can arise when using the model for predicting yield, given the fact that the ground information is neither particularly representative nor directly guaranteed by PV manufacturers. In fact, the authors of widely-used software based on this model duly warn users about the lack of PV manufacturers' commitment. Notable examples are the disclaimer in the PVsyst User's Guide: “..for definitive simulations, the user is advised to carefully verify the library data with the last manufacturer's specifications...We drop out any responsibility about the integrity and the exactness of the data and performance including in the library..", and the explanations of the CECPV calculator: "Information presented on this page does not demonstrate performance over time...All parties should perform their own due diligences on all equipment" [117].

On the other hand, the MPP models appear to be closer to the PV manufacturers' guarantees. In fact, $P_{M P P}^{*}$ is just the main guaranteed value and, as mentioned above, our experience suggests that PV manufacturers are prone to also provide a guarantee for $\gamma$. This is

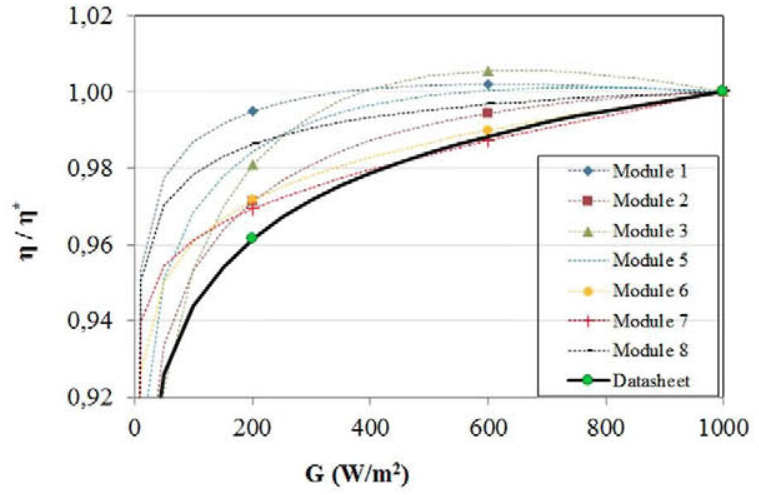

(a)

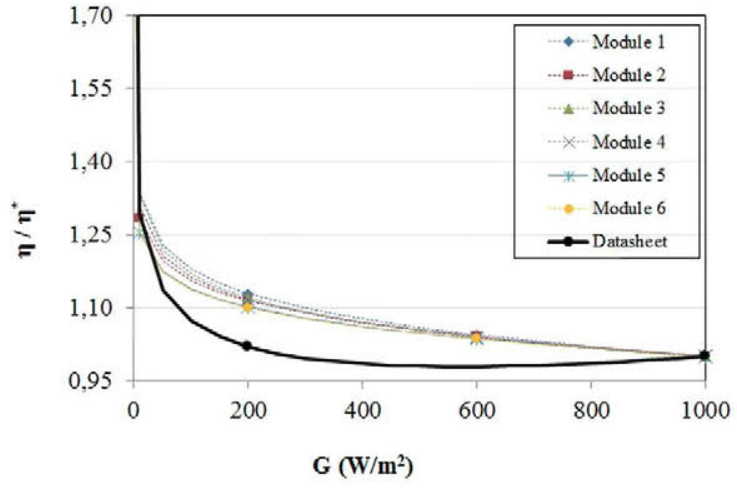

(b)


to datasheet information. 
Table 3

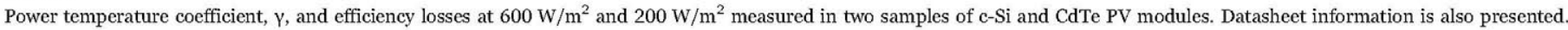

\begin{tabular}{|c|c|c|c|c|c|c|}
\hline & \multicolumn{3}{|l|}{$\mathrm{c}-\mathrm{Si}$} & \multicolumn{3}{|l|}{ CdTe } \\
\hline & $Y\left(\% /{ }^{\circ} \mathrm{C}\right)$ & $1-\eta^{\prime}(0.6)(\%)$ & $1-\eta^{\prime}(0.2)(\%)$ & $\gamma\left(\% /{ }^{\circ} \mathrm{C}\right)$ & $1-\eta^{\prime}(0.6)(\%)$ & $1-\eta^{\prime}(0.2)(\%)$ \\
\hline M1 & -0.428 & -0.21 & 0.47 & -0.28 & -4.5 & -12.9 \\
\hline M2 & -0.399 & 0.56 & 2.84 & -0.25 & -4.1 & -11.5 \\
\hline M3 & -0.41 & -0.55 & 1.89 & -0.27 & -4.0 & -12.1 \\
\hline M4 & -0.412 & -0.04 & 1.54 & -0.27 & -4.0 & -11.7 \\
\hline M5 & -0.404 & 1 & 2.82 & -0.29 & -3.6 & -10.2 \\
\hline M6 & -0.422 & 1.28 & 3.04 & -0.24 & -3.6 & -10.1 \\
\hline M7 & -0.4 & 1.15 & 1.34 & -0.27 & -4.0 & -11.4 \\
\hline Average & -0.41 & 0.46 & 1.99 & -0.27 & -4 & -11.4 \\
\hline Datasheet & -0.41 & $1.4^{(*)}$ & 4.50 & -0.25 & $-0.6^{(1)}$ & -2 \\
\hline
\end{tabular}

$\left(^{*}\right)$ No information is given on datasheet. Eq. (25) has been applied.

important because thermal losses (due to $T_{\mathrm{C}} \neq T_{\mathrm{C}}{ }^{*}$ ) are particularly relevant to the energy balance of a PV plant. Concerns regarding low light performance still arise. Related datasheet information is the value of $\eta^{\prime}(0.2)$ and, when EN 50380 is observed, also $\eta^{\prime}(0.8)$ which is easily deduced from $P_{\mathrm{MPP}}$ (NOTC) and $\gamma$ values. In principle, this makes it possible to solve the parameters of Eq. (23). In the event that only $\eta^{\prime}(0.2)$ is known, then the approximation given by Eq. (25) is always conservative, thereby maintaining the chain of responsibility.

\subsubsection{Additional independent information}

Granting generality to values measured on particular PV specimens or relying on certain assumptions allows for easy fitting of I-V curve models. In fact, this is the path followed by some software that is widely used today, such as PVsyst and CECPV calculator. As mentioned above, such software duly warns users regarding the lack of commitment by PV manufacturers.

On similar lines, independent testing organizations sometimes publish efficiency versus temperature and irradiance values measured on particular specimens. For example, the JRC of ISPRA has published efficiency values at different irradiances for a number of technologies [62] . Again, granting generality to these values permits the fitting of MPP models. However, responsibility concerns arise again when using the model for predicting yield, because this information is likely to be affected by module-to-module variations and it is not directly guaranteed by PV manufacturers.

\subsubsection{Operational information}

This section refers to possible data from outdoor measurements once the PV plant is in operation. It is worth noting that I-V curves close to $1 \mathrm{MW}$ have been measured [118,119]. However, uncertainty concerns arise with the I-V curves of such large PV arrays, mainly due to the dispersion of $T_{\mathrm{C}}$ in the case of large areas and almost instantaneous observations (I-V sweeps are typically below $30 \mathrm{~ms}$ ). Interestingly, standard IEC 62446 (Grid connected photovoltaic systems: Minimum requirements for system documentation, commissioning tests and inspection) explicitly mentions that the $V_{\mathrm{OC}}$ and $I_{\mathrm{SC}}$ tests it prescribes are simply for verifying correct installation but not test performance.

It seems much better to rely on $P_{\mathrm{MPP}}$ records for relatively extensive routine operating periods, for example, a minimum of one full day. Due to the fact that the MPP tracking efficiency of current inverters is usually greater than $99 \%, P_{\mathrm{MPP}}$ can be properly understood as the power at the inverter entry. Moreover, the $G$ and $T_{\mathrm{C}}$ values can also be recorded simultaneously. Then, taking particular precautions regarding irradiance sensors, such as its calibration and stability, leads to low uncertainty $P_{M P P}^{*}$ measurements [120], which can be used to check

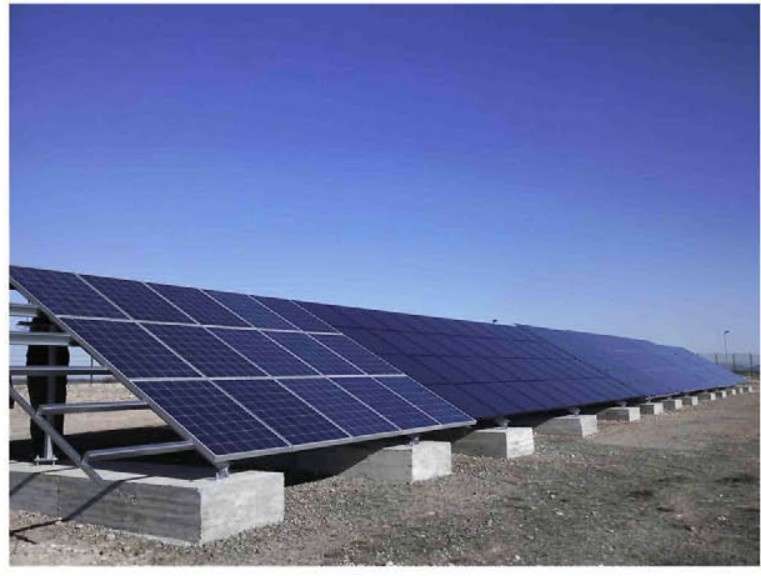

Fig. 3. General view of the PV arrays.

compliance with contractual requirements and also for the routine monitoring of PV plant operation, by comparing real energy production values with the corresponding estimates from the $G$ and $T_{\mathrm{C}}$ records.

Obviously, it is only possible to derive $P_{M P P}^{*}$ values from $\left(P_{\mathrm{MPP}}, G\right.$, $T_{\mathrm{C}}$ ) records with MPP models, whilst this is not possible with I-V models. This is one of the main reasons why, after achieving similar accuracy (this is discussed later on in this paper), an MPP model and not an I-V one was selected to implement SISIFO, an open access software program under the umbrella of the European project PVCROPS [121]. The same reason has led other authors to adopt MPP models instead of I-V ones [122].

\section{Experimental comparison}

In order to provide an empirical base for evaluating PV performance models, $5 \mathrm{PV}$ arrays of different technologies (polycrystalline silicon $\mathrm{c}-\mathrm{Si}$, CdTe, CIGS, and two double junction a-Si/ $\mu \mathrm{Si}$ from different manufacturers), each with $P_{M P P, N O M}^{*}$ between $1890 \mathrm{~W}$ and $2400 \mathrm{~W}$, were connected to the grid by $2.5 \mathrm{~kW}$ inverters, in Navarra (Spain). All the PV generators are static, tilted $30^{\circ}$, oriented due South and fully free from shading (Fig. 3). Because PV power is always lower than the inverter capacity, it never reaches saturation, so that PV arrays are continuously maintained at the maximum power point. $P_{\mathrm{MPP}}$ at the inverter entry, $G$ and $T_{\mathrm{C}}$ are measured at $1 \mathrm{~s}$ intervals and recorded as $10 \mathrm{~min}$ averages. Moreover, once per month and taking advantage of clear days, the systems are disconnected for a few minutes and PV 
Table 4

Main features of the PV arrays tested.

\begin{tabular}{|c|c|c|c|c|c|c|c|}
\hline Manufacturer & Generator & $\mathbf{P}_{\text {Nameplate }} / \operatorname{module}$ & Total modules & Total Nameplate Power & $\mathrm{Y}\left(\% /{ }^{\circ} \mathrm{C}\right)$ & $\beta\left(\% /{ }^{\circ} \mathrm{C}\right)$ & $\alpha\left(\% /{ }^{\circ} \mathrm{C}\right)$ \\
\hline M1 & Si & 160 & 14 & 2240 & -0.45 & -0.37 & 0.10 \\
\hline M2 & $a-S i / \mu S i$ & 130 & 18 & 2340 & -0.28 & -0.33 & 0.06 \\
\hline M3 & $a-S i / \mu S i$ & 135 & 14 & 1890 & -0.24 & -0.30 & 0.07 \\
\hline M4 & CIGS & 107 & 18 & 1926 & -0.446 & -0.357 & -0.003 \\
\hline M5 & CdTe & 175 & 30 & 2250 & -0.25 & -0.27 & 0.04 \\
\hline
\end{tabular}

arrays I-V curves are measured. Tables 4 and 5 respectively show the main features of the PV arrays and the instruments used.

Ideally, $G$ is directly given by PV reference devices of the same technology and level of soiling as the corresponding PV arrays. However, due to the stability issue of TF materials, c-Si reference modules entail less uncertainty and are currently more widely accepted by the market actors than TF ones. Taking this into account, it was decided to measure $G$ with only two c-Si reference PV modules, located at the PV arrays surface extremes. Other authors adhere to the same practice $[41,64,74,123,124]$. Differences between the irradiance measurements of these two reference modules are always lower than $1 \%$, suggesting that dust cover is homogeneous over the entire PV array surface, so that it can be disregarded in the analysis. $T_{\mathrm{C}}$ is measured through thermocouples placed in the centre of the rear side of two modules of each PV array (approximately, $10 \%$ of the total number of modules). The temperature differences from these two thermocouples were always lower than $2{ }^{\circ} \mathrm{C}$, suggesting that averages are very representative of the entire PV array operating temperature.

Further equipment included a meteorological station with a horizontal pyranometer, a shaded pyranometer and a thermocouple, which were able to record the following variables: broadband global radiation; diffuse radiation; and air temperature.

\subsection{Weather and operating conditions}

Measurements were performed over the period from March 2011 to February 2016. Table 6 and Fig. 4 summarize the main characteristics of the observed ambient conditions: broadband horizontal daily irradiation, $G_{d}^{B B}(0)$, and average ambient temperature during the day, $T_{\Lambda}$. Roughly, they correspond to a sunny place with larger temperature variations from winter to summer. Operating conditions are also given, in terms of in-plane effective daily irradiation, $G_{d}$, and the equivalent $\mathrm{PV}$ module temperature, $T_{\mathrm{CEQ}}$, defined as the average of $T_{\mathrm{C}}$ weighted by irradiance. $T_{\mathrm{CEQ}}$ values correspond to $\mathrm{M} 1$. It is worth mentioning that differences between the different technologies are below $3.5^{\circ} \mathrm{C}$. Fig. 4 shows the annual distribution of these irradiances and temperatures.

\subsection{Selected models}

Seeking to represent the range of modelling possibilities, the ones described in Table 7 have been selected for MPP models and Table 8 for IV curve models. In addition, Table 9 shows the equations used for the
Table 6

Main characteristics of both the observed ambient conditions and operation conditions.

\begin{tabular}{llllll}
\hline & \multicolumn{2}{l}{ Weather } & & \multicolumn{2}{l}{ Operation conditions } \\
\cline { 2 - 3 } \cline { 5 - 6 } & $G_{d}^{B B}(0) \mathrm{kW} \mathrm{h} / \mathrm{m}^{2}$ & $T_{\mathrm{A}}\left({ }^{\circ} \mathrm{C}\right)$ & & $G_{d} \mathrm{~kW} \mathrm{~h} / \mathrm{m}^{2}$ & $T_{\mathrm{C}, \mathrm{EQ}}\left({ }^{\circ} \mathrm{C}\right)$ \\
\hline Average & 4.44 & 16.86 & & 4.79 & 33.03 \\
Worst month & 1.20 & 6.28 & & 1.96 & 18.10 \\
Best month & 7.86 & 27.03 & & 7.50 & 46.21 \\
\hline
\end{tabular}

resolution of the curve and Table 10 shows whether the IV curve was solved using an iterative method or an analytical method.

\subsection{Results}

Comparison is performed in terms of the daily energy errors, which is relevant for energy yield forecast, and in terms of the weekly $P R$ and $P R_{\text {STC }}$ consistency throughout the year, which is relevant for on-site measurement campaigns. The $P^{*}$ values were the nominal ones, referred to as nameplate values in Table 4.

In order to consider their real impact on energy yield calculations, the errors were weighted by the respective daily irradiation [126]. Therefore, the Error and the Weighted Error at day "i" are respectively given by Eq. (42) and Eq. (43):

$E_{i}=\left(\frac{E_{M O D, i}-E_{E X P, i}}{E_{E X P, i}}\right)$

$W E_{i}=E_{i} \frac{G_{e f f d, i}}{\left(\sum_{i=1}^{N} G_{e f f d, i}\right) / N}$

Where $E_{\mathrm{MOD}}$ and $E_{\mathrm{EXP}}$ represent the daily modelled and experimental PV array energy values, $G_{\text {effd }}$ the daily effective irradiation and $N$ extends to the number of days for the considered period. It is worth noting that the Mean Bias Weighted Error, given by Eq. (44), is equal to the error on the energy calculated for such period.

The evaluations metrics that have been considered are:

- Fitting to the experimental measurement, calculated through the relative Mean Bias Weighted Error (MBWE), according to Eq. (44):

Table 5

Installed data acquisition equipment, sensors, and uncertainties.

\begin{tabular}{|c|c|c|}
\hline Parameter & Manufacturer & Maximum uncertainty \\
\hline DC Voltage & Yokogawa & $\pm(0.2 \%$ of reading $+0.2 \%$ of range $)$ \\
\hline DC Current & Yokogawa & $\pm(0.2 \%$ of reading $+0.2 \%$ of range $)$ \\
\hline DC Active Power & Yokogawa & $\pm(0.3 \%$ of reading $+0.2 \%$ of range $)$ \\
\hline IV Characteristic & Photovoltaik Engineering & $<1 \%$ \\
\hline Pt100 Temperature & Omega & $\begin{array}{l}\text { B Class }= \pm 0.3^{\circ} \mathrm{C} \text { at nominal resistance }\left(0^{\circ} \mathrm{C}\right) \\
\text { B Class }= \pm 0.8^{\circ} \mathrm{C} \text { at nominal resistance }\left(100^{\circ} \mathrm{C}\right)\end{array}$ \\
\hline Global Radiation $30^{\circ}$ mc-Si reference modules & Yingli Solar & $\pm 2 \%\left(\right.$ Calibrated by CIEMAT $\left.{ }^{3}\right)$ \\
\hline
\end{tabular}

\footnotetext{
a CIEMAT: Centre for Energy-Related, Environmental and Technological Research.
} 


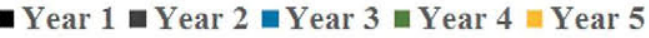

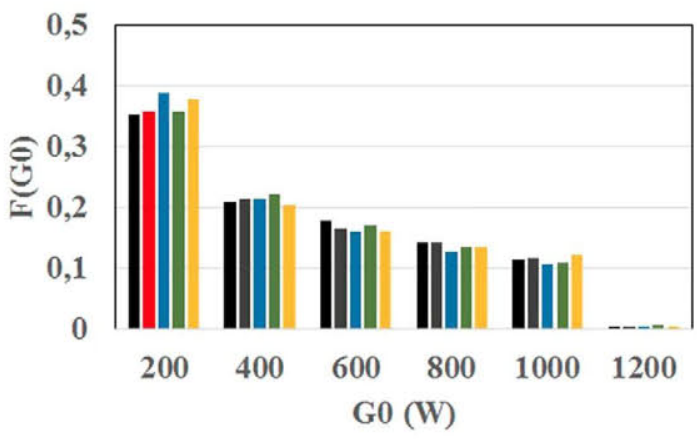

(a)

-Year 1 -Year 2 -Year 3 -Year 4 "Year 5

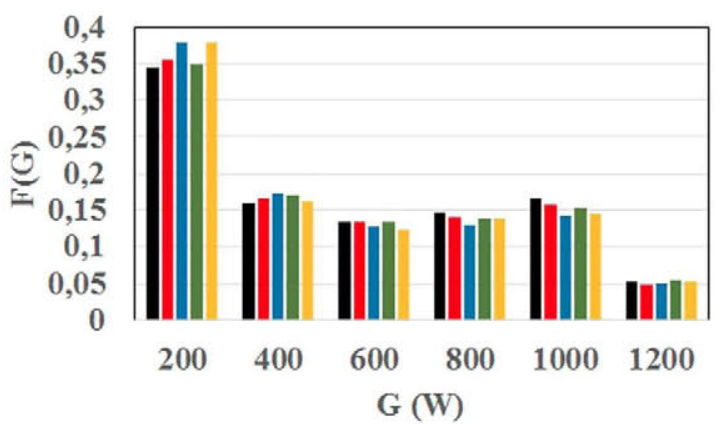

-Year 1 -Year 2 -Year 3 -Year 4 Year 5

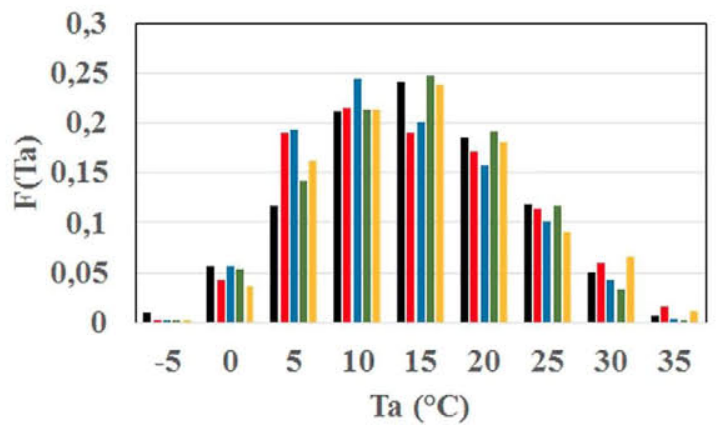

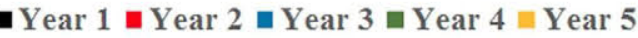

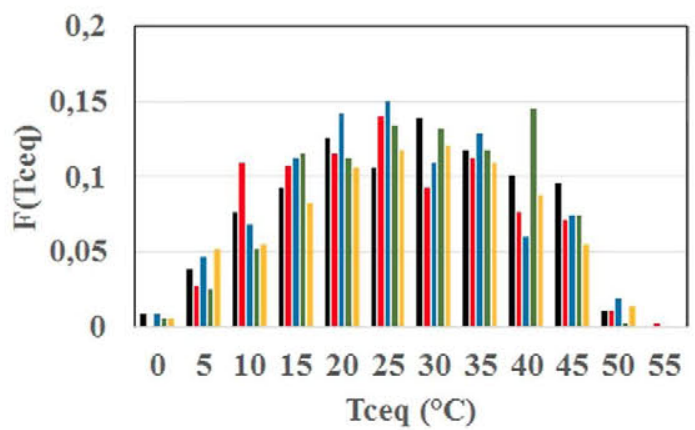

(b)

Fig. 4. Observed distribution of a) ambient and b) operation conditions.

Table 7

Selected MPP models.

\begin{tabular}{|c|c|c|c|c|}
\hline \multicolumn{5}{|c|}{ Empirical or MPP models } \\
\hline Type & $\begin{array}{l}\text { Input data } \\
\text { (source) }\end{array}$ & Eqs. & $\begin{array}{l}\text { No. of } \\
\text { Parameters }\end{array}$ & Nomenclature \\
\hline $\begin{array}{l}\text { Constant } \\
\text { efficiency }\end{array}$ & $P_{M P P}^{*}$ (datasheet) & (19) & 1 & $\mathrm{MPP}_{\eta=\text { cte }}$ \\
\hline \multirow{3}{*}{$\begin{array}{c}\text { T-dependent } \\
\text { efficiency }\end{array}$} & $P_{M P P}^{*}, \gamma$ (datasheet) & (20) & 2 & $\mathrm{MPP}_{\eta(\mathrm{T}) \mathrm{Y}}$ \\
\hline & $\begin{array}{l}P_{M P P}^{*}, \alpha, \beta \\
\text { (datasheet) }\end{array}$ & $\begin{array}{l}(21), \\
\xi=0\end{array}$ & 3 & $\mathrm{MPP}_{\eta(\mathrm{T})} \alpha \beta$ \\
\hline & $\begin{array}{l}P_{M P P}^{*}, \alpha, \beta, \xi \\
\text { (datasheet) }\end{array}$ & (21) & 4 & 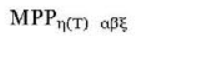 \\
\hline \multirow{6}{*}{$\begin{array}{l}\text { G and T- } \\
\text { dependent } \\
\text { efficiency }\end{array}$} & $\begin{array}{l}P_{M P P}^{*}, \gamma, \eta_{(200)} \\
\text { (datasheet) }\end{array}$ & $\begin{array}{l}(23) \\
(25)\end{array}$ & 3 & $\mathrm{MPP}_{\eta(G, T)(200)}$ \\
\hline & $\begin{array}{l}P_{M P P}^{*}, \gamma, \eta_{(200)}, \eta_{(800)} \\
\text { (datasheet) }\end{array}$ & $\begin{array}{l}(23), \\
(25)\end{array}$ & 4 & $\mathrm{MPP}_{\eta(\mathrm{G}, \mathrm{T})}(200,800)$ \\
\hline & $\begin{array}{l}P_{M P P}^{*}, \gamma \\
\text { (datasheet), } \\
a_{1}, a_{2}, \quad a_{3} \text { from } \\
{[62]}\end{array}$ & (23) & 5 & $\mathrm{MPP}_{\mathrm{n}(\mathrm{G}, \mathrm{T}) \text { (Kenny) }}$ \\
\hline & $\begin{array}{l}P_{M P P}^{*}, \gamma \\
\text { (datasheet) }\end{array}$ & (23) & 5 & $\mathrm{MPP}_{\eta(G, \mathrm{~T})(\mathrm{exp})}$ \\
\hline & $\begin{array}{l}a_{1}, \quad a_{2}, \\
\text { (experimental) }\end{array}$ & & & \\
\hline & $\begin{array}{l}P_{M P P}^{*} \text { (datasheet), } \\
k_{1}, k_{2}, k_{3}, k_{4}, k_{5}, k_{6} \\
\text { from }[83]\end{array}$ & (36) & 7 & $\mathrm{MPP}_{\mathrm{\eta (G,T)} \text { (Huld) }}$ \\
\hline
\end{tabular}

$M B W E=\frac{1}{N} \cdot \sum_{i} W E_{i}$

- Dispersion around the fit, through the relative Root Mean Square Weighted Error (RMSWE), according to Eq. (45):
$R M S W E=\frac{1}{N} \cdot \sqrt{\sum_{i} W E_{i}^{2}}$

\subsubsection{Crystalline silicon}

4.3.1.1. Daily energy errors. For explanatory purposes, the particular

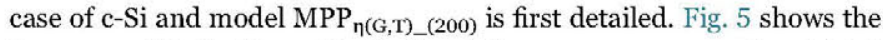
frequency distribution of both the daily energy errors and weighted daily energy errors and its relationship with the daily clearness index, $K_{\text {Td. }}$. Corresponding mean bias error, MBE, and mean bias weighted error, MBWE, are $-2.11 \%$ and $2.39 \%$ with corresponding root mean square error, RMSE, and root mean square weighted error, RMSWE, are $-3.31 \%$ and $1.33 \%$. Note that the radiation weighting factor reduces the general uncertainty of the models and implies a reduction of the error on cloudy days when the energy impact is much lower. The following comments apply:

- The MBE and MBWE errors obviously depend on the difference between the nominal and the actual peak power value. In fact, $P^{*}$ values deduced from our I-V measurements suggest the actual STC power is $1-2 \%$ greater than the nominal value, which is probably due to the positive tolerance $(0,+3 \%)$ of the PV manufacturing process. This value was further confirmed by testing 2 of the constituent modules at two independent laboratories: CIEMAT (Research Centre on Energy, Environment and Transports) and CENER (National Renewable Energy Centre). The later means that a good model is expected to underestimate around $1-2 \%$.

The lower $K_{\text {Td }}$ is the higher $E$. Slight differences on the angular response of different PV modules of the same type can help to explain this result. Whatever the case, the impact of cloudy days on total energy error, observable on the $W E$ versus $K_{\text {Td }}$ figure, is very low. 
Table 8

Selected I-V curve models.

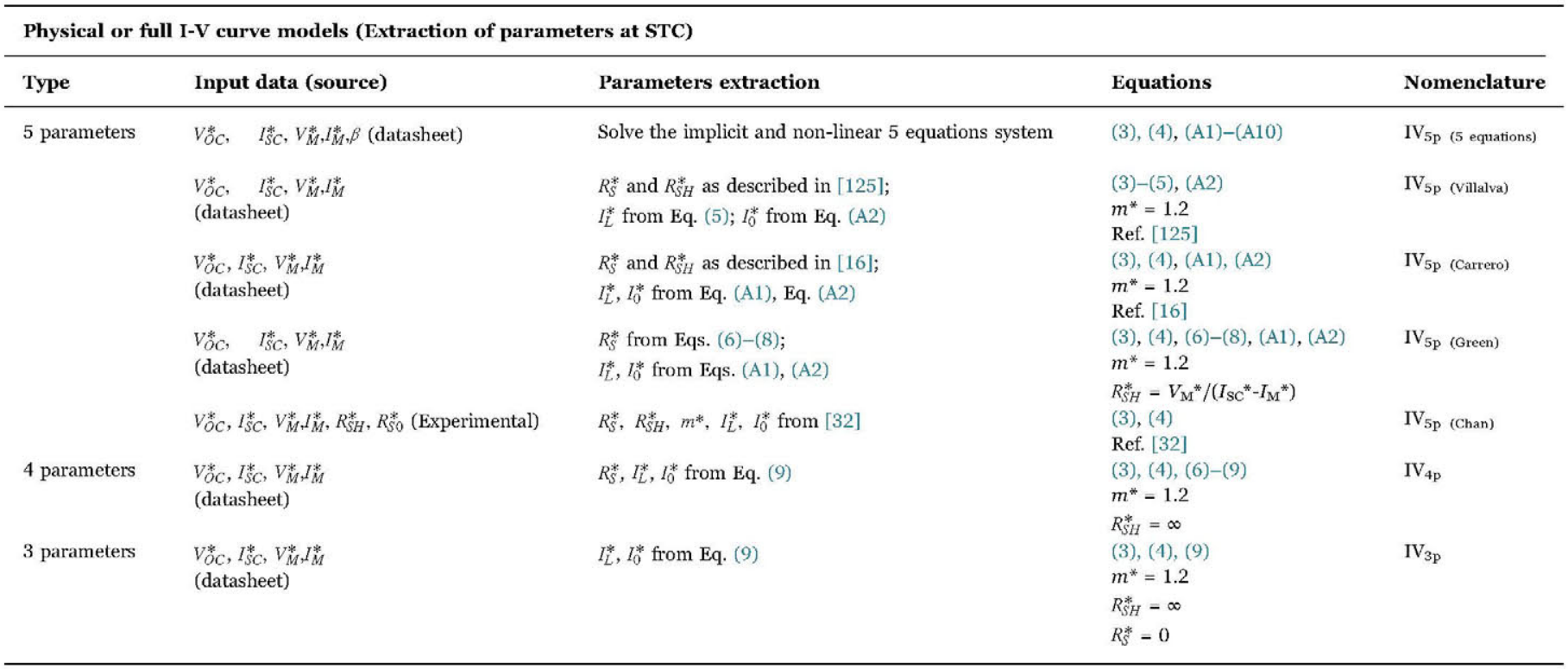

Table 9

Nomenclature for extension to arbitrary operating conditions.

\begin{tabular}{ll}
\hline $\begin{array}{l}\text { Physical or full I-V curve models (Extension to arbitrary operation } \\
\text { conditions) }\end{array}$ \\
\hline Option & Equations \\
& $m=m^{*}, R_{S}=R_{S}^{*}$ \\
\hline E1 & $R_{S H}$ from Eq. (14) \\
& $I_{L}$ from Eq. (11) \\
& $I_{O}$ from Eqs. (12), (13) \\
E2 & $R_{S H}$ from Eq. (14) \\
& $I_{L}$ from Eq. (11) \\
& $I_{O}$ from Eqs. (3), (16) \\
E3 & $R_{S H}$ from Eq. (15) \\
& $I_{L}$ from Eq. (11) \\
& $I_{O}$ from Eqs. (12), (13) \\
E4 & $R_{S H}$ from Eq. (15) \\
& $I_{L}$ from Eq. (11) \\
& $I_{o}$ from Eqs. (3), (16) \\
\hline
\end{tabular}

Table 10

Nomenclature for solving the I-V curve for MPP.

\begin{tabular}{ll}
\hline Physical or full I-V curve models (Solving the model for MPP value) \\
\hline Option & Method \\
\hline S1 & Iterative (Newton-Raphson) \\
S2 & Analytical (Annex II) \\
\hline
\end{tabular}

Tables 11 and 12 give the 5 year MBWE and RMSWE errors for all the considered models. Comments are:

- Regarding to MPP models, those with just three independent parameters perform as well as any other ones.

- The use of published values for polycrystalline modules $\left(\mathrm{MPP}_{\mathrm{\eta}(\mathrm{G}, \mathrm{T})}\right.$ (Kenny) performs better than the use of a generic c-Si model
(MPP

- Thermal and low irradiance losses account for about $4.2 \%$ and $0.9 \%$, respectively $\left(\Delta E_{\mathrm{TC} \neq \mathrm{TC}}{ }^{*}\right.$ and $\Delta E_{\mathrm{G} \neq \mathrm{G}}$ are calculated as the MBWE difference between $\mathrm{MPP}_{\eta=\text { constant }}$ and $\mathrm{MPP}_{\left.\eta_{\eta(T) \_}\right\rangle}$models, and between $\mathrm{MPP}_{\eta(\mathrm{T}) \_\gamma}$ and $\mathrm{MPP}_{\eta(\mathrm{G}, \mathrm{T})(200)}$ models, respectively). Obviously, these results are local dependent. Hence, it is appropriate to mention that winter in Navarra is both sunny and cool.

- Somewhat surprisingly, when considering only the variation of the efficiency with $T_{\mathrm{C}}$ but disregarding the effects of $G$, the $\mathrm{MPP}_{\eta(\mathrm{T})}$ y performs very well. In order to further explain this result, which is consistent with the energy loses balance mentioned above, Fig. 6 plots ratio $\Delta E_{\mathrm{RP}} / \Delta E_{\mathrm{RS}}$ versus $K_{\mathrm{Td}}$, as given by $\mathrm{MPP}_{\eta(\mathrm{G}, \mathrm{T}) \_(\exp ) \text {, where }}$ $\Delta E_{\mathrm{RP}}$ and $\Delta E_{\mathrm{RS}}$, respectively, represents the daily energy losses and gains due to $R_{\mathrm{P}}$ and $R_{\mathrm{S}}$ effects. They cancel each other out for $K_{\mathrm{Td}} \approx$ 0.45 and they perform asymmetrically with respect to $K_{\mathrm{Td}}: R_{\mathrm{S}}$ gains for $K_{\mathrm{Td}}>0.45$ are lower than $R_{\mathrm{P}}$ losses for $K_{\mathrm{Td}}<0.45$. The figure also helps to understand that this result is local and PV module dependent.

- In all the IV models simulated with E1-S2 and E2-S2, the results are exactly the same, which is a consequence of using the same $\mathrm{V}_{\mathrm{OC}}$ values for both E1 and E2.

- IV models simulated with E2 appear to perform better than E1. This is a reasonable occurrence due to the fact that $\mathrm{E} 2$ takes into consideration coefficient $\beta$ of the datasheet module while E1 considers the general silicon $E_{g}$ value.

- IV models simulated with E3 seem to perform better than E1. This fact implies that the calculation of $R_{\mathrm{sh}}$ through Eq. (15) is better than through Eq. (14).

- Similarly, IV models simulated with E4 appear to perform better than E2 which leads to the same conclusion as for the previous point.

- IV models are rather sensitive to $R_{\mathrm{P}}$ assumptions, as shown by the differences between $\mathrm{IV}_{4 \mathrm{p}}\left(R_{\mathrm{sh}}{ }^{*}=\infty\right)$ and $\mathrm{IV}_{5 \mathrm{p} \_(5 \text { equations })}\left(R_{\mathrm{P}}{ }^{*}=\right.$ $60 \Omega$ ), and between E1-E2 ( $R_{\mathrm{P}}$ versus $G$ as per Eq. (15)) and E3-E4 $\left(R_{\mathrm{P}}\right.$ versus $G$ as per Eq. (14)) for $\mathrm{IV}_{5 \mathrm{p}_{-}(\mathrm{Green})}$ and $\mathrm{IV}_{5 \mathrm{p} \_ \text {(Villalva) }}$ models.

- Models based on experimental measurements (IV5p_(Chan)) do not 


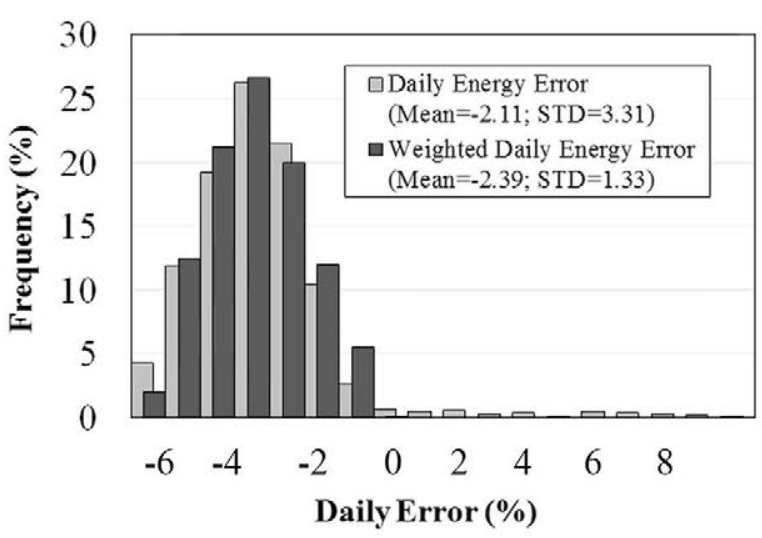

(a)

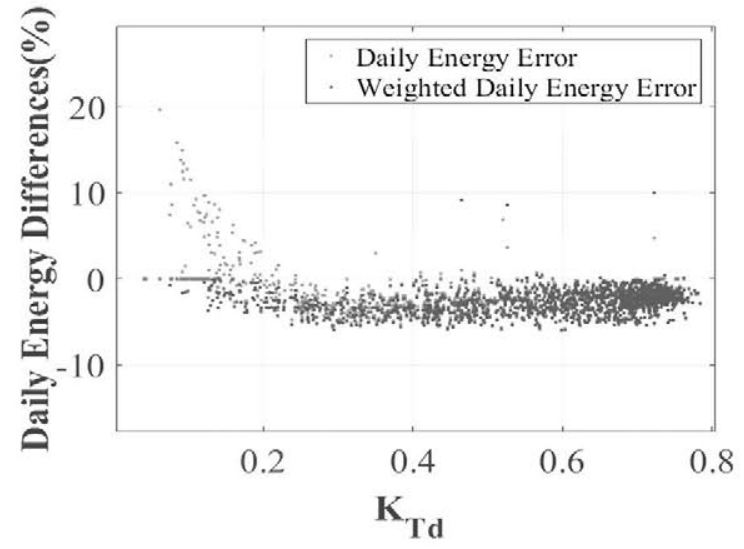

(b)

Fig. 5. a) Observed frequency distribution of the daily energy errors and weighted errors for the MPP $\left.{ }_{\eta(G,} \mathrm{T}\right)(200,800)$ model. (b) Its relation with the clearness index of the day.

Table 11

MBWE and corresponding RMSWE for the MPP models.

\begin{tabular}{|c|c|c|}
\hline \multicolumn{3}{|l|}{ MPP models } \\
\hline Model & MBWE & RMSWE \\
\hline $\mathrm{MPP}_{\eta=\text { cte }}$ & 2.72 & 6.51 \\
\hline $\mathrm{MPP}_{\eta(\mathrm{T}) \mathrm{y}}$ & -1.43 & 1.25 \\
\hline $\mathrm{MPP}_{\mathrm{n}(\mathrm{T}) \text { a } \beta}$ & 0.13 & 2.81 \\
\hline $\mathrm{MPP}_{\eta(T)}$ aßk & -1.40 & 1.26 \\
\hline$M P P_{\eta(G, T)}(200)$ & -2.39 & 1.33 \\
\hline $\mathrm{MPP}_{\eta(\mathrm{G}, \mathrm{T})}(200,800)$ & -2.05 & 1.19 \\
\hline $\mathrm{MPP}_{\eta(\mathrm{G}, \mathrm{T}) \text { (Kenny) }}$ & -1.30 & 1.09 \\
\hline $\mathrm{MPP}_{\eta(\mathrm{G}, \mathrm{T})}$ (exp) & -1.00 & 1.08 \\
\hline$M P P_{\eta(G, T)}$ (Huld) & -2.61 & 1.15 \\
\hline
\end{tabular}

seem to be better than the others.

- The model that uses the 5 parameters obtained by solving the implicit and non-linear 5 equations system performs worse than the others.

- The analytical procedure proposed by Ruiz for solving the MPP point of an I-V curve is very convenient. It is extremely easy to implement and the associated errors are insignificant, as revealed by the similarity of $\mathrm{IV}_{5 \mathrm{p} \text { (Green) }}(\mathrm{S} 1$ and $\mathrm{S} 2$ ) results.

Table 13 summarizes the observed errors in daily energy estimates from selected models (the best IV curve models have been selected). In order to consider their real impact on energy yield calculations, the errors are weighted by the respective daily irradiation. Average errors are mainly due to differences between real and nominal STC power (Pnominal-Preal $=-1$ to $2 \%$ ). Root mean square weighted errors are due to model uncertainties and to slight differences on the angular response of the PA arrays and the reference module sensing irradiance.

4.3.1.2. Performance indices. Fig. 7a) shows the observed evolution of the weekly $P R^{D C}$ and $P R_{S T C}^{D C}$, again from March 2011 to February 2016. It is worth noting that, in an endeavour to avoid any uncertainty included by the inverters, the PR has been calculated with DC power values. Thermal and irradiance losses have been calculated with the $\mathrm{MPP}_{\eta(\mathrm{G}, \mathrm{T})(200)}$ model. As expected, the $P R_{S T C}^{D C}$ performs significantly more consistently, allowing for a much sounder technical quality evaluation on the basis of the energy production observed in relatively short periods. Note that the slightly seasonal performance of $P R_{S T C}^{D C}$ may be caused by differences between the datasheet value of $\gamma$ and its real value. Fig. $7 \mathrm{~b}$ ) shows the frequency distribution of the weekly $P R^{D C}$ and $P R_{S T C}^{D C}$. The corresponding mean bias error and root mean square error values are, respectively, 0.99 and 0.05 for the $P R^{D C}$ and 1.02 and 0.01 for the $P R_{S T C}^{D C}$. From our experience and in order to deal with the $P R^{D C}$, some technical quality evaluations have been made on the basis of observed $P R^{D C}$ values, by considering a different reference value for each month. The 12 reference $P R^{D C}$ values are established by a simulation exercise on the basis of solar radiation and ambient temperature databases. However, the validity of this $P R^{D C}$ monthly correction procedure is probably not general but restricted to particular climatic regions. In fact, our results show weekly $P R^{D C}$ variations of up to $5 \%$ for the same month, which seems inadequate for large scale PV plant qualification.

\subsubsection{The case of thin-film technologies}

As has been seen in the previous section, the performance of simple MPP models with just three independent parameters, such as $\mathrm{MPP}_{\eta(\mathrm{T}) \_\gamma}$, $\mathrm{MPP}_{\eta(\mathrm{T}) \_\alpha \beta}$ or $\mathrm{MPP}_{\eta(G, T) \_(200)}$, is similar to the most complex models. Therefore, only the three mentioned MPP models were simulated for the thin-film case. Those IV curve models which perform better for the c-Si were also simulated for the thin-film case. Table 14 shows the results for the thin-film cases: $a-S i / \mu S i, C I G S$ and $C d T e$. The STC power outputs measured at each PV generator and referred to the nameplate power are shown below each technology in Table 14. It is worth mentioning that average errors are mainly due to differences between real and nominal STC power (except in the CIGS case where it has been experimentally checked that low irradiances losses are higher than the datasheet value). This problem is also addressed in other studies [127,128]. The same comments concerning the $\mathrm{Si}-\mathrm{x}$ case can be considered. It is worth noting that the higher RMSWE implies that the uncertainty associated with the models is also higher, together with the difficulty of finding typical values of some of the characteristic parameters within manufacturers datasheets or the literature.

\section{Conclusions}

The review carried out for the currently available PV performance models permits a comparison of full I-V curve and MPP models alike, with regard to accuracy and also compliance with datasheet specifica- 
Table 12

MBWE and corresponding RMSWE for the IV curve models.

\begin{tabular}{|c|c|c|c|c|}
\hline \multicolumn{5}{|c|}{ I-V curve models } \\
\hline Model & $\begin{array}{l}\text { Extension to } \\
\text { arbitrary operation } \\
\text { conditions }\end{array}$ & $\begin{array}{l}\text { Solving the } \\
\text { model }\end{array}$ & MBWE & RMSWE \\
\hline \multirow[t]{8}{*}{$\mathrm{IV}_{5 \mathrm{p} \text { (5 equations) }}$} & \multirow[t]{2}{*}{ E1 } & $\mathbf{S 1}$ & -5.59 & 3.36 \\
\hline & & S2 & -5.62 & 3.37 \\
\hline & \multirow[t]{2}{*}{$\mathrm{E} 2$} & S1 & -5.62 & 3.37 \\
\hline & & S2 & -7.60 & 3.47 \\
\hline & \multirow[t]{2}{*}{$\mathrm{E} 3$} & $\mathbf{S 1}$ & -7.71 & 3.47 \\
\hline & & S2 & -7.60 & 3.47 \\
\hline & \multirow[t]{2}{*}{$\mathrm{E} 4$} & S1 & -7.60 & 3.47 \\
\hline & & S2 & -7.60 & 3.47 \\
\hline \multirow{8}{*}{$\Gamma_{5 p}$ (villalva) } & \multirow[t]{2}{*}{$\mathrm{E} 1$} & $\mathbf{S 1}$ & -1.24 & 1.53 \\
\hline & & S2 & -0.42 & 2.55 \\
\hline & \multirow[t]{2}{*}{$\mathrm{E} 2$} & $\mathbf{s 1}$ & -0.43 & 2.54 \\
\hline & & S2 & -0.42 & 2.55 \\
\hline & \multirow[t]{2}{*}{ E3 } & $\mathbf{S 1}$ & -5.64 & 2.42 \\
\hline & & S2 & -4.58 & 3.15 \\
\hline & \multirow[t]{2}{*}{$\mathrm{E} 4$} & $\mathbf{S 1}$ & -4.58 & 3.15 \\
\hline & & $\mathbf{S 2}$ & -4.58 & 3.15 \\
\hline \multirow[t]{8}{*}{$\mathrm{IV}_{5 \mathrm{p} \text { (Carrero) }}$} & \multirow[t]{2}{*}{ E1 } & $\mathbf{s 1}$ & -1.87 & 1.26 \\
\hline & & S2 & -0.94 & 1.30 \\
\hline & \multirow[t]{2}{*}{$\mathrm{E} 2$} & $\mathbf{S 1}$ & -0.94 & 1.30 \\
\hline & & $\mathbf{S 2}$ & -0.94 & 1.30 \\
\hline & \multirow[t]{2}{*}{$\mathrm{E} 3$} & s1 & -3.77 & 1.44 \\
\hline & & S2 & -2.70 & 1.52 \\
\hline & \multirow[t]{2}{*}{$\mathrm{E} 4$} & s1 & -2.70 & 1.52 \\
\hline & & S2 & -2.70 & 1.52 \\
\hline \multirow[t]{8}{*}{$\mathrm{IV}_{5 \mathrm{p} \text { (Green) }}$} & \multirow[t]{2}{*}{ E1 } & $\mathbf{s 1}$ & -2.30 & 1.84 \\
\hline & & S2 & -1.32 & 1.17 \\
\hline & \multirow[t]{2}{*}{$\mathrm{E} 2$} & $\mathbf{S 1}$ & -1.32 & 1.17 \\
\hline & & S2 & -1.32 & 1.17 \\
\hline & \multirow[t]{2}{*}{ E3 } & $\mathbf{S 1}$ & -3.20 & 1.85 \\
\hline & & S2 & -2.16 & 1.23 \\
\hline & \multirow[t]{2}{*}{ E4 } & $\mathbf{S 1}$ & -2.16 & 1.23 \\
\hline & & S2 & -2.16 & 1.23 \\
\hline \multirow[t]{8}{*}{$\mathrm{IV}_{5 \mathrm{p} \text { (Chan) }}$} & E1 & $\mathbf{S 1}$ & 3.76 & 4.26 \\
\hline & & S2 & 1.78 & 1.62 \\
\hline & $\mathrm{E} 2$ & $\mathbf{s 1}$ & 1.77 & 1.62 \\
\hline & & S2 & 1.78 & 1.62 \\
\hline & E3 & $\mathbf{S 1}$ & 1.25 & 4.24 \\
\hline & & S2 & -0.63 & 1.61 \\
\hline & $\mathrm{E} 4$ & $\mathbf{S 1}$ & -0.63 & 1.61 \\
\hline & & S2 & -0.63 & 1.61 \\
\hline IV $4 p$ & $\mathrm{E} 1-\mathrm{E} 3\left(R_{S H}=\infty\right)$ & $\mathbf{s 1}$ & -2.27 & 2.21 \\
\hline & & S2 & -1.26 & 1.24 \\
\hline & $\mathrm{E} 2-\mathrm{E} 4\left(R_{S H}=\infty\right)$ & S1 & -1.26 & 1.24 \\
\hline & & \$2 & -1.26 & 1.24 \\
\hline$\Gamma_{3_{\mathrm{p}}}$ & E1 $\left(R_{S H}=\infty\right.$ and $\left.R_{s}=0\right)$ & $\mathbf{S 1}$ & 8.18 & 5.05 \\
\hline & & S2 & 9.22 & 6.28 \\
\hline & $\mathrm{E} 2\left(R_{S H}=\infty\right.$ and $\left.R_{s}=0\right)$ & $\mathbf{S 1}$ & 9.22 & 6.28 \\
\hline & & S2 & 9.22 & 6.28 \\
\hline
\end{tabular}

tions and guarantees. Accuracy was assessed through a meticulous measurement campaign conducted on PV arrays of four different technologies at a PV plant. The main conclusions of this comparison are outlined below:

- MPP models with just three independent parameters suffice to accurately describe the relationship between PV array performance and operating conditions. Moreover, these parameters are easily



Fig. 6. Daily ratio between energy losses due to $R_{P}$ and energy gains due to $R_{S}$ versus clearness index.

Table 13

Summary of some of the MBWE and RMSWE for the selected models.

\begin{tabular}{|c|c|c|c|}
\hline Model & Number of input parameters & MBWE & RMSWE \\
\hline \multicolumn{4}{|l|}{ MPP models } \\
\hline $\mathrm{MPP}_{\eta(\mathrm{T}) \text { y }}$ & 2 & -1.43 & 1.25 \\
\hline $\mathrm{MPP}_{\eta(G, T)}(200)$ & 3 & -2.39 & 1.33 \\
\hline $\mathrm{MPP}_{\eta(\mathrm{G}, \mathrm{T})}$ (Huld) & 7 & -2.61 & 1.15 \\
\hline \multicolumn{4}{|l|}{ I-V curve models } \\
\hline $\mathrm{IV}_{5 \mathrm{p}}$ (Carrero),E1,S2 & 5 & -0.94 & 1.30 \\
\hline $\mathrm{IV}_{5 \mathrm{p}}$ (Green),E1,S2 & 5 & -1.32 & 1.17 \\
\hline $\mathrm{IV}_{5 \mathrm{p},(\mathrm{Chan}), \mathrm{E} 1, \mathrm{~S} 2}$ & 5 & 1.78 & 1.62 \\
\hline IV4p,E1-E3 $(R S H=\infty), \mathrm{S} 2$ & 4 & -1.26 & 1.24 \\
\hline
\end{tabular}

derived from standard datasheet information. In contrast, physical models and MPP models with more than three parameters do not improve accuracy but increase complexity and move away from the manufacturers' specifications. Hence, their use in engineering practices, despite the fact that they are currently widely used, is scarcely justified.

- Besides, model feedback from actual situations is far easier for MPP models than for physical ones, because records of routine operation of PV plants typically include power records at the inverter entry but not full I-V curves of the PV arrays. Therefore, MPP models provide a direct way for not only advanced operational monitoring but also for linking initial energy yield expectations, which are always at the core of commercial PV plant projects, and further observed performance realities, opening the doors for clear diagnosis and endorsement of responsibilities in the event of underperformance. This represents a great advantage in the context of Technical Quality Assurance Procedures.

- The modelling of the performance of Thin Film technologies using only the standard available information requires particular assumptions regarding seasonal variations and the Staebler-Wronski effect. This paper considers that CdTe and CIGS perform similarly to c-Si and that seasonal variations of a-Si/ $\mu \mathrm{c}-\mathrm{Si}$ are well described by a sinusoidal function with an amplitude of $3.5 \%$ of STC power. In this case, the uncertainty associated with the models is greater, together with the difficulty of finding typical values of some of the characteristic parameters within manufacturer's datasheets or the literature. 


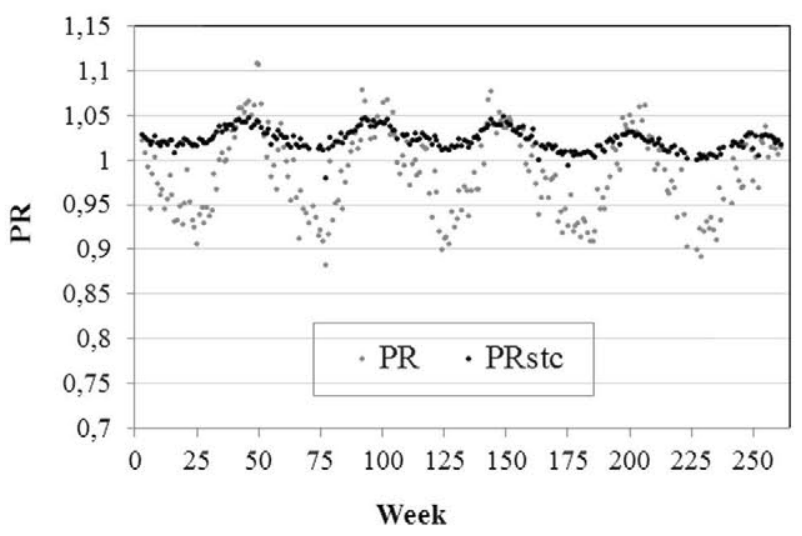

(a)

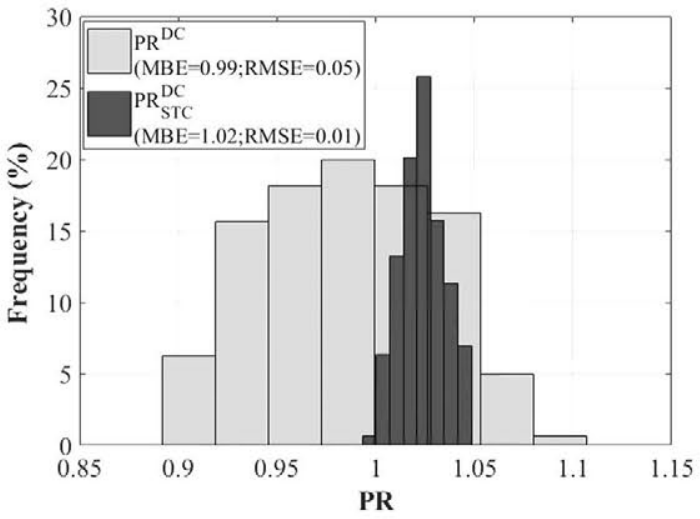

(b)

Fig. 7. a) Observed evolution of the weekly $P R^{D C}$ and $P R_{S T C}^{D C}$ and b) frequency distribution of the weekly $P R^{D C}$ and $P R_{S T C}^{D C}$. during the analyzed period.

Table 14

MBWE and corresponding RMSWE for the selected MPP models for the thin-film cases.

\begin{tabular}{|c|c|c|c|c|c|c|c|c|c|}
\hline \multirow[t]{2}{*}{ Models } & & \multicolumn{2}{|c|}{$\begin{array}{l}\mathrm{a}-\mathrm{Si} / \mu \mathrm{Si} M 1 \\
\left(\mathrm{P}^{*}=0.85\right)\end{array}$} & \multicolumn{2}{|c|}{$\begin{array}{l}\mathrm{a}-\mathrm{Si} / \mu \mathrm{Si} \mathrm{M} 2 \\
\left(\mathrm{P}^{*}=0.86\right)\end{array}$} & \multicolumn{2}{|c|}{$\begin{array}{l}\text { CIGS } \\
\left(P^{*}=0.99\right)\end{array}$} & \multicolumn{2}{|c|}{$\begin{array}{l}\text { CdTe } \\
\left(P^{*}=0.97\right)\end{array}$} \\
\hline & & MBWE & RMSWE & MBWE & RMSWE & MBWE & RMSWE & MBWE & RMSWE \\
\hline \multirow[t]{3}{*}{ MPP Models } & $\mathrm{MPP}_{\eta(T) \text { y }}$ & 15.94 & 7.56 & 16.06 & 7.35 & 5.17 & 3.53 & 4.41 & 4.00 \\
\hline & $M P P_{\eta(T)} \alpha \beta$ & 16.00 & 7.62 & 16.10 & 7.40 & 5.99 & 3.69 & 4.56 & 4.02 \\
\hline & $\mathrm{MPP}_{\eta(\mathrm{G}, \mathrm{T})(200)}$ & 14.78 & 7.44 & 14.55 & 7.19 & 4.22 & 3.29 & 1.54 & 3.94 \\
\hline \multirow[t]{5}{*}{ IV Models } & $\mathrm{IV}_{5 \mathrm{p}}$ (Villalva),E1,S2 & 19.35 & 9.79 & 20.08 & 9.84 & 5.51 & 5.56 & 1.35 & 2.70 \\
\hline & $\mathrm{IV}_{5 \mathrm{p}}$ (Villalva),E3,S2 & 17.06 & 9.38 & 18.11 & 9.45 & 6.64 & 7.08 & 1.22 & 3.20 \\
\hline & $\mathrm{IV}_{5 \mathrm{p} \text { (Green),E1,S2 }}$ & 18.88 & 7.17 & 18.80 & 7.24 & 4.53 & 6.21 & 1.67 & 2.80 \\
\hline & $\mathrm{IV}_{5 \mathrm{p}}$ ( Green),E3,S2 & 18.52 & 7.06 & 18.49 & 7.15 & 4.62 & 6.07 & 1.60 & 2.80 \\
\hline & IV4p, E1-E3 $(R S H=\infty), \mathrm{S} 2$ & 18.89 & 7.04 & 18.90 & 7.16 & 4.63 & 6.58 & 1.82 & 2.61 \\
\hline
\end{tabular}

\section{Acknowledgements}

The authors would like to thank ACCIONA for authorizing measurements at its PV plants and for the helpful collaboration of its staff.
This work has been supported by the Spanish State Research Agency (AEI) and FEDER-UE under grants DPI2016-80641-R and DPI201680642-R.

\section{Annex 1. I-V model related equations}

\section{A.1. Extraction parameters}

Writing Eq. (3) for $I_{\mathrm{SC}^{*}}, V_{\mathrm{OC}}{ }^{*}$ and $\left(I_{\mathrm{M}}{ }^{*}, V_{\mathrm{M}}{ }^{*}\right)$ gives, respectively Eqs. (A1)-(A3)

$I_{S C}^{*}=I_{L}^{*}-I_{0}^{*}\left(\exp \frac{I_{S C}^{*} R_{S}^{*}}{V_{t}^{*}}-1\right)-\frac{I_{S C}^{*} R_{S}^{*}}{R_{S H}^{*}}$

$0=I_{L}^{*}-I_{0}^{*}\left(\exp \frac{V_{O C}^{*}}{V_{t}^{*}}-1\right)-\frac{V_{O C}^{*}}{R_{S H}^{*}}$



Imposing the derivative of power in the MPP point is zero gives Eq. (A4):

$\frac{d P}{d V}=\frac{d(I V)}{d V}=I+V \frac{d I}{d V}$

$d I / d V$ is obtained by observing that the mathematical model (Eq. (3)) is of the shape $I=f(I, V)$. Then, $d I / d V$ is given by Eq. (A5) 
$d I=d I \frac{\partial f(I, V)}{\partial I}+d V \frac{\partial f(I, V)}{\partial V}$

or Eq. (A6)

$\frac{d I}{d V}=\frac{\frac{\partial f(I, V)}{\partial V}}{1-\frac{\partial f(I, V)}{\partial I}}$

partial derivatives are given by Eq. (A7)

$\frac{\partial f(I, V)}{\partial V}=-\frac{I_{0}}{V_{t}} \exp \frac{V+I R_{S}}{V_{t}}-\frac{1}{R_{P}}$ and $\frac{\partial f(I, V)}{\partial I}=-\frac{I_{0} R_{S}}{V_{t}} \exp \frac{V+I R_{S}}{V_{t}}-\frac{R_{S}}{R_{P}}$

and writing the condition $(\mathrm{d} P / \mathrm{d} V)_{\mathrm{MPP}}=0$ for STC gives Eq. (A8)

$I_{M}^{*}+V_{M}^{*} \frac{-\frac{I_{0}^{*}}{V_{t}^{*}} \exp \frac{V_{M}^{*}+I_{M}^{*} R_{S}^{*}}{V_{t}^{*}}-\frac{1}{R_{P}^{*}}}{1+\frac{I_{0}^{*} R_{s}^{*}}{V_{t}^{*}} \exp \frac{V_{M}^{*}+I_{M}^{*} R_{S}^{*}}{V_{t}^{*}}+\frac{R_{S}^{*}}{R_{P}^{*}}}=0$

It is worth noting that the same equation is obtained from recognizing that the slope of the I-V curve at MPP is [26,54] and given by Eq. (A9):

$\left.\frac{d I}{d V}\right|_{M P P}=-\frac{I_{M}}{V_{M}}$

The fifth equation derives from writing Eq. (A2) for $G^{*}$ and $T_{\mathrm{C}}$, taking into account the dependence on temperature of $I_{\mathrm{L}}, I_{0}$ and $R_{\mathrm{SH}}$, as described in (11), (12), and considering that the open circuit temperature coefficient is defined as Eq. (A10)

$V_{O C}\left(T_{C}\right)=V_{O C}^{*}\left[1+\beta\left(T_{C}-T_{C}^{*}\right)\right]$

Giving Eq. (A11):

$0=I_{L}^{*}\left[1+\alpha\left(T_{C}-T_{C}^{*}\right)-I_{0}^{*}\left(\frac{T_{C}}{T_{0}^{*}}\right)^{3} \exp \left[\frac{E_{g}}{k}\left(\frac{1}{T_{C}^{*}}-\frac{1}{T_{C}}\right)\left(\exp \frac{V_{O C}^{*}\left[1+\beta\left(T_{C}-T_{C}^{*}\right)\right]}{V_{t}^{*} \frac{T_{C}}{T_{C}^{*}}}-1\right)-\frac{V_{O C}^{*}\left[1+\beta\left(T_{C}-T_{C}^{*}\right)\right]}{R_{S H}^{*}}\right.\right.$

The particular temperature value is not critical, since any $T_{\mathrm{C}}$ ranging from 1 to $10 \mathrm{~K}$ above or below $T_{\mathrm{C}}{ }^{*}$ gives the same result.

Finally, it is worth mentioning that another alternative item of information derives from establishing a relationship between $m$ and $R_{\mathbf{P}}$ [30]. This is given by Eq. (A12):

$V_{t}^{*}=\frac{V_{M}^{*}+I_{M}^{*} R_{S}^{*}-V_{O C}^{*}}{\ln \left[\frac{\left(I_{S C}^{*}-I_{M}^{*}\right)\left(1+\frac{R_{S}^{*}}{R_{P}^{*}}\right)+\frac{V_{O C}^{*}-v_{M}^{*}}{R_{P}^{*}}}{I_{S C}^{*}\left(1+\frac{R_{S}^{*}}{R_{P}^{*}}\right) \frac{V_{O C}^{*}}{R_{P}^{*}}}\right]}$

A.2. Analytical equations for solving Eq. (3) for MPP. Eqs. (A13)-(A17) apply

$D_{M 0}=\frac{v_{O C}-1}{v_{O C}-\ln v_{O C}} \quad D_{M}=D_{M 0}+2 r_{S} D_{M 0}^{2}$

$i_{s}=\frac{1-g_{p}\left(1-r_{s}\right)}{1-\exp \left(-v_{o c}\left(1-r_{s}\right)\right)}$

$i_{s}^{\prime}=1+\dot{i}_{s} \exp \left[-v_{o c}\left(1-r_{s}\right)\right] \quad v_{s}^{\prime}=1-\frac{1}{v_{o c}} \ln \left(v_{o c} i_{s}\right)$

$i_{M}^{\prime}=i_{s}^{\prime}-\frac{D_{M}}{v_{o c}} \quad v_{M}^{\prime}=v_{s}^{\prime}+\frac{1}{v_{o c}} \ln D_{M}$

$\frac{I_{M}}{I_{S C}}=i_{M}^{\prime}-g_{p}\left(v_{M}^{\prime}-r_{s}\right) \quad \frac{V_{M}}{V_{O C}}=v_{M}^{\prime}-\frac{I_{M}}{I_{S C}} r_{s}$

where the normalized conductance is $g_{\mathrm{p}}=1 / r_{\mathrm{P}}$ and $v_{O C}, r_{\mathrm{S}}$ and $r_{\mathrm{P}}$ are given by Eq. (6) written without asterisks. For extension of $V_{O C}$ and $I_{S C}$ at arbitrary conditions the following equations Eqs. (A18) and (A19) are used:

$V_{O C}=V_{O C}^{*}\left[1-\beta T^{\prime}\right]+V_{t} l n G^{\prime}$

$I_{S C}=I_{S C}^{*} G^{\prime}\left[1+\alpha\left(T_{C}-T_{C}^{*}\right)\right]$ 


\section{References}

[1] Kenny PR, Dunlop ED, Ossenbrink HA, Müllejans H. A practical method for the energy rating of c-Si PV modules based on standard tests. Progr Photovolt: Res Appl 2006:155-66. http://dx.doi.org/10.1002/pip658.

[2] Loferski J. The first forty years: a brief history of the modern photovoltaic age. Prog Photovolt: Res Appl 1993;1:67-8. http://dx.doi.org/10.1002/pip.

[3] Balasubramanian B, AA. Performance evaluation of solar photovoltaic (PV) array based on mathematical and simulation modelling: a review. Aust J Basic Appl Sci 2014:469-77.

[4] Ma T, Hongxing Y, Lu L. Solar photovoltaic system modelling and performance prediction. Renew Sustain Energy Rev 2014:304-15.

[5] Rus-Casas C, Aguilar JD, Rodrigo P, Almonacid F, Pérez-Higueras PJ. Classification of methods for annual energy harvesting calculations of photovoltaic generators. Energy Convers Manag 2014:527-36.

[6] Backus CE. Solar cells. IEEE Press; 1976. [s.1.].

[7] Green M. Solar cells: operating principles, technology and system applications. Prentice Hall; 1982. [s.l.].

[8] Duffie JA, Beckman WA. Solar engineering of thermal process. New York: John Wiley and Sons; 1991.

[9] Lorenzo E. Solar electricity: engineering of photovoltaic systems. Sevilla: Progensa; 1994.

[10] De Soto W, Klein SA, Beckman WA. Improvement and validation of a model for photovoltaic array performance. Sol Energy 2006:78-88. http://dx.doi.org/ 10.1016/j.solener.2005.06.010.

[11] Jakhrani A, Samo S, Kamboh S, Labadin J, Rigit A. An improved mathematical model for computing power output of solar photovoltaic modules. Int $J$ Photoenergy 2014. http://dx.doi.org/10.1155/2014/346704.

[12] Ghani F, Duke M, Carson J. Extration of solar cell modelling parameters using the Lambert W-function. 50th Annual conference. Australian Solar Energy Society, Melbourne; 2012. [s.n.]

[13] Lo Brano V, Orioli A, Ciulla G, Di Cangi A. An improved five-parameters model for photovoltaic modules. Sol Energy Mater Sol Cells 2010:1358-70.

[14] Laudani A, Mancilla-David F, Riganti-Fulginei F, Salvini A. Reduced-form of the photovoltaic five-parameter model for efficient computation of parameters. Sol Energy 2013:122-7.

[15] Lo Brano V, Ciulla G. An efficient analytical approach for obtaining a five parameters model of photovoltaic modules using only reference data. Appl Energy 2013:849-903.

[16] Carrero C, Rodriguez J, Rmírez D, Platero C. Simple estimation of PV modules loss resistances for low error modelling. Renew Energy 2010:1103-8.

[17] Sera D, Teodorescu R, Rodriguez P. PV panel model based on datasheets values. IEEE Trans Power Electron 2007:2392-6.

[18] Villalva MG, Gazoli JR, Filho ER. Comprehensive approach to modelling and simulation of photovoltaic arrays. IEEE Trans Power Electron 2009:1198-208.

[19] Jia Q, Anderson W. A novel approach for evaluating the series resistance of solar cells. Sol Cells 1988:311-8.

[20] Celik AN, Acikgoz N. Modelling and experimental verification of the operating current of mono-crystalline photovoltaic modules using four and five parameter models. Appl Energy 2007:1-15.

[21] Bashahu M, Habyarimana A. Review and test of methods for determination of the solar cell series resistance. Renew Energy 1995:129-38.

[22] Bellini A, Bifaretti S, Iacovone V, Cornaro C. Simplified model of a photovoltaic module. Appl Electron 2009:47-51.

[23] Hernandez J, Vallejo W, Gordillo G. Practical method for estimating the power and energy delivered by photovoltaic modules operating under non-standard conditions. Progr Photovol: Res Appl 2013:867-75. http://dx.doi.org/10.1002/ pip. 2168.

[24] Massi Pavan A, Mellit A, Lughi V. Explicit empirical model for the general photovoltaic devices: experimental validation at maximum power point. Sol Energy 2014:105-16.

[25] Mahmoud Y, Xioa W, Zeineldin H. A simple approach to modelling and simulation of photovoltaic modules. IEEE Trans Sustain Energy 2010:185-6.

[26] Saloux E, Teyssedou A, Sorin M. Explicit model of photovoltaic panels to determine voltages and currents at the maximum power point. Sol Energy 2011:713-22.

[27] Vajpai J, Khyani H. Mathematical modelling and experimental validation of performance characteristics of solar photovoltaic modules. Int J Appl Or Innov Eng Manag 2013:295-301.

[28] Charles JP, Abdelkrim M, Muoy YH, Mialhe P. A practical method for analysis of I-V characteristics of solar cells. Sol Cells 1981:169-78.

[29] Phang JCH, Chan DSH, Phillips JR. Accurate analytical method for the extraction of solar cell model parameters. Electron Lett 1984:406-8.

[30] Jia QX, Ebihara K, Ikegami T. Analytical solution for solar cell model parameters from illuminated current-voltage characteristics. Philos Mag B 1995:375-82.

[31] Chan D, Phillips J, Phang J. A comparative study of extraction methods for solar cell model parameters. Solid-State Electron 1986:329-37.

[32] Chan DSH, Phang JC. Analytical methods for the extraction of solar-cell single and double-diode model parameters from I-V characteristics. IEEE Trans Electron Dev 1987;34:286-93.

[33] de Blas M, Torres J, Prieto E, García A. Selecting a suitable model for characterizing photovoltaic devices. Renew Energy 2002:371-80.

[34] Haouari-Merbah M, Belhamel M, Tobias I, Ruiz JM. Extraction and analysis of solar cells parameters from the illuminated current-voltage. Sol Energy Mater Sol Cells 2005, [pp. 225-33].
[35] Bashahu M, Nkundabakura P. Review and tests of methods for the determination of the solar cell junction ideality factors. Sol Energy 2007;81:856-63.

[36] Bouzidi K, Chegaar M, Bouhemadou A. Solar cells parameters evaluation considering the series and shunt resistance. Sol Energy Mater Sol Cells 2007:1647-51.

[37] Tsuno Y, Hishikawa Y, Kurokawa K. Modelling I-V curves of PV modules using linear interpolation/extrapolation. Technical digest of the international PVSEC17. Fukuoka; 2007. [s.n.].

[38] Zhou W, Yang H, Fang Z. A novel model for photovoltaic performance prediction. Appl Energy 2007:1187-98.

[39] Kim W, Choi W. A novel parameter extraction method for the one-diode solar cell model. Sol Energy 2010:1008-19.

[40] Dongue SB, Njomo D, Ebengai L. An improved nonlinear five-point model for photovoltaic modules. Int J Photoenergy 2013. http://dx.doi.org/10.1155/2013/ 680213.

[41] Stein J, Suttrelueti J, Ransome S, Hansen CW, King BH. Outdoor Performance Evaluation of Three Different Models: Single-diode, SAPM and Loss Factor Model. SAND Report 2013-7913C. 2013.

[42] Singh NS, Jain A, Kapoor A. An exact analytical method for calculating the parameters of a real solar cell using special trans function theory (STFT). Int $J$ Renew Energy Res 2013:201-6.

[43] Venkateswarlu G, Sangameswar R. Modeling and parameter extraction of PY modules using genetic algorithms and differential evaluation. IOSR J Electr Electron Eng 2013:37-44.

[44] Ortiz-Conde A, Garcia Sanchez FJ, Muci J, Sucre-Gonzalez A. A review of diode and solar cell equivalent circuit model lumped parameter extraction procedures. Facta Univ Electron Energ 2014:57-102. http://dx.doi.org/10.2298/ FUEE14010570.

[45] Ma T, Yang H, Lu L. Development of a model to simulate the performance characteristics of crystalline silicon photovoltaic modules/strings/arrays. Sol Energy 2014:31-41.

[46] PVsyst. PVsyst photovoltaic software. [Online] 227 2016. 〈http://www.pvsyst. $\mathrm{com} / \mathrm{en} /\rangle$.

[47] GOsolarCalifornia. GOsolarCalifornia. [Online] 217 2016. 〈http://www. gosolarcalifornia.org/tools/nshpcalculator/index.php).

[48] Messenger RA, Ventre S. Photovoltaics system engineering, $2^{\circ}$ Ed. Boca Ratón (FL): CRC Press LLC; 2004.

[49] Mermoud A, Lejeune T. Performance assessment of a simulaion model for PV modules of any available technology. 25th European photovoltaic solar energy conference. Valencia; 2010. [s.n.].

[50] Boyd T, Klein S, Reindl T, Dougherty B. Evaluation and validation of equivalent circuit photovoltaic solar cell performance models. J Sol Energy Eng 2011. http:// dx.doi.org/10.1115/1.4003584.

[51] Siddiqui M, Abido M. Parameter estimation for five- and seven-parameter photovoltaic electrical models using evolutionary algorithms. Appl Soft Comput 2013:4608-21.

[52] Yordanov, HG. The PVGIS relative efficiency model: equations for K1-K6. 29th European photovoltaic solar energy conference and exhibition. 2014. p. 3297301.

[53] Akbaba M, Alattawi M. A new model for I-V characteristic of solar cell generators and its applications. Sol Energy Mater Sol Cells 1995:123-32.

[54] Xiao W, Dunford W, Capel A. A novel modelling method for photovoltaic cells. 35th Annual IEEE power electronics specialist conference. Aachen; 2004. p. 1950-56. [ s.n.].

[55] Evans D. Simplified method for predicting photovoltaic array ouput. Sol Energy 1981:555-60.

[56] Osterwald. Translation of device performance measurements to reference conditions. Solar Cells. 1986, p. 269-79.

[57] Fuentes M, Nofuentes G, Aguilera J, Talavera D, Castro M. Application and validation of algebraic methods to predict the behaviour of crystalline silicon PV modules in Mediterranean climates. Sol Energy 2007:1396-408.

[58] Randall JF, Jacot J. Is AM1.5 applicable in practice? Modelling eight photovoltaic materials with respect to light intensity and two spectra. Renew Energy 2003:1851-64.

[59] Willians SR, Betts TR, Helf T, Gottschalg R, Beyer GH, Infield DG. Modelling longterm module performance based on realistic reporting conditions with consideration to spectral effects. 3rd World conference on photovoltaic energy conversion. Osaka, Japan; 2003. p. 1908-11. [s.n.].

[60] Beyer HG, Betcke J, Drews A, Heinemann D, Lorenz E, Heilscher G, et al. Identification of a general model for the MPP performance of PV-modules for the application in a procedure for the performance check of grid connected systems. 19th European photovoltaic solar energy conference. Paris; 2004. p. 443-7.[s.n.].

[61] Reich NH, van Sark WGJHM, Alsema EA, Lof RW, Schropp REI, Sinke WC, et a] Crystalline silicon cell performance at low intensities. Sol Energy Mater Sol Cells 2009:1471-81.

[62] Kenny RP, Vigano D, Solis E, Bardizza G, Norton H, Müllejans Zaaiman W. Power rating of photovoltaic modules including validation of procedures to implement IEC61853-1 on solar simulators and under natural sunlight. Progr Photovolt 2013. http://dx.doi.org/10.1002/pip.2365.

[63] Willian SR, Betts TR, Gottschalg R, Infield DG, Moor H, van der Borg N, et al Accuracy of energy prediction methodologies. 4th IEEE world conference on photovoltaic energy conversion. Hawai; 2006. p. 2206-9. [s.n.].

[64] Friesen G, Gottschalg R, Beyer H, Willinas S, Guerin de Montgareuil A, van der Borg $\mathrm{N}$, et al. Intercomparison of different energy prediction methods within the European project "PERFORMANCE". 22nd European photovoltaic solar energy conference. Milan; 2007. p. 2659-63. [s.n.]. 
[65] EPIA. IP-Performance. Setting the standards for the PV industry. Free available at 〈www.pv-performance.org), 2009. [s.l.].

[66] TamiizhMani G, Kuitvhe J, Mikonovich A. A solar ABCs proposed standard on: nameplate, datasheet and sampling requirements of photovoltaic modules. Solar America Board for Codes an Standards ssolarabcs.org/about/publications/ reports/nameplate/indx.ht $|m\rangle$, 2012. [s.l.].

[67] Roy Jyotirmoy,.... Validation of proposed photovoltac energy rating standard and sensitivity to environmental parameters. 23rd European photovoltaic solar energy conference. Valencia; 2008. p. 2728-34. [s.n.].

[68] Poissant Y, Pelland S, Turcotte D. A comparison of energy rating methodologies using field test measurements. 23rd European PVSEC. Valencia; 2008. p. 265762. [s.n.].

[69] Dirnberger D, Müller B, Reise C. PV module energy rating: opportunities and limitations. Progr Photovolt: Res Appl 2015. http://dx.doi.org/10.1002/pip.2618, [p. published on line]

[70] Müller B, Kräling U, Heydenreich W, Reise Gh, Kiefer K. Simulation of irradiation and temperature dependent efficiency of thin film and crystalline silicon modules based on different parametrization. 25th European PVSEC. Valencia; 2010. p. 4240-3. [s.n.].

[71] Durisch W, Bitnar B, Mayor J, Kiess H, Lam K, Close J. Efficiency model for photovoltaic modules and demostration of its application to energy yield estimation. Sol Energy Mater Sol Cells 2007;91:79-84.

[72] Hamou S, Zine S, Abdellah R. Efficiency of PV module under real working conditions. Energy Procedia 2014;50:553-8.

[73] Ransome S, Sutterlueti J. Improving and understanding $\mathrm{kW} \mathrm{h} / \mathrm{kWp}$ simulations. 26th European PVSEC. Hamburg; 2011. [s.n.].

[74] Sellner S, Sutterlini J, Schereier L, Ransome S. Advanced PV module performacne characterization and validation using the novel loss factors model. 38th IEEE PVSC. Austin, Texas; 2012. p. 2938-43. [s.n.].

[75] Ransome S, Sutterlueti J, Sellner S. PV technology differences and discrepancies in modelling between simulation programs and measurements. 38 IEEE PVSC. Austin, Texas; 2012. [s.n.].

[76] Torres-Ramírez M, Nofuentes G, Silva JP, Silvestre S. Study on analytical modelling approaches to the performance of thin film PV modules in sunny inland climates. Energy 2014:1-10.

[77] King DL, Kratochvil JA, Boyson WE, Bower WI. Field experience with a new performance characterization procedure for photovoltaic arrays. 2nd World conference and exhibition on photovoltaic solar energy conversion. Vienna; 1998, [s.n.].

[78] King DL, Boyson WE, Kratochvill JA. Photovoltaic array performance model. Sandia report SAND2004-3535. 2004.

[79] NREL. NREL System Advisor Model (SAM). [Online] 217 2016. 〈https://sam. nrel.gov/>.

[80] Willians S, Betts T, Gottschalg R, Infield D, Van der Borg N, Burgers A, et al Evaluating the state of the art of photovoltaic performance modelling in Europe. 20th Europen PVSEC. Barcelona; 2005. [s.n.].

[81] PVGIS. PVGis. [Online] 227 2016. 〈http://photovoltaic-software.com/pvgis.php $\rangle$.

[82] Huld T, Suri M, Dunlop E. Greographical variation of the conversion efficiency of crystalline silicon photovoltaic modules in Europe. Progr Photovolt: Res Appl 2008:595-607. http://dx.doi.org/10.1002/pip.846.

[83] Huld T, Friesen G, Skoczek A, Kenny RP, Sample T, Field M, et al. A power-rating model for crystalline silicon PV modules. Sol Energy Mater Sol Cells 2011:3359-69.

[84] Taylor RW. System and module rating: advertised versus actual capability. Sol Cells 1986, [pp. 335-44].

[85] Rosell JI, Ibáñez M. Modelling power output in photovoltaic modules for outdoor operating conditions. Energy Convers Mang 2006:2424-30.

[86] Heydenreich W, Müller B, Reise C. Describing the world with three parameters: a new approach to PV module power modelling. 23rd EUPVSEC. Valencia; 2008. p. 2786-9. [s.n.].

[87] Montgareuil AG, Sicot L, Martin JL, Mezzasalma F, Delesse Y, Merten J. A new tool for the MotherPV method: Modelling of the irradiance coefficientn of photovoltaic modules. 24th EUPVSEC. Hamburgo; 2009. p. 3305-9. [s.n.].

[88] Silva JP, Asenjo B, Vela N, Chenlo F. Caracterización de módulos fotovoltaicos de diversas tecnologías. ERA Sol 2014:42-7.

[89] Staebler DL, Wronski CR. Reversible conductivity changes in discharge-produced amorphous Si. Appl Phys Lett 1977;31:292.

[90] Dunn, Gostein M, L. Light soaking effects on photovoltaic modules: overview and literature review. Proceedings 37th IEEE PVSC. 2011. p. 3126-31.

[91] Marin M, Muñoz-García O. Characterization of thin-film PV modules under standard test conditions: results of indoor and outdoor measurements and the effects of sunlight exposure. Sol Energy 2012;86(10):3049-56.

[92] Nascimento LR, Rüther RA. Avaliaçao de Longo prazo de um sistema fotovoltaico integrado à edificação urbana e conectado à rede elétrica pública. Rev Bras De Energ Sol V 2014:73-81.

[93] Rüther R, Livingstone J. Seasonal variations in amorphous silicon solar module outputs and thin film characteristics. Sol Energy Mater Sol Cells 1994;36:29-43.

[94] Rüther R, Kleiss G, Reiche K. Spectral effects on amorphous silicon solar module fill factors. Sol Energy Mater Sol Cells 2002;71:375-85.

[95] Gopttschalg R, Betts TR, Infield DG, Keamey MJ. The effect of spectral variations on the performance parameters of single and double junction amorphous silicon solar cells. Sol Energy Mater Sol Cells 2005;85:415-28.

[96] Fanni A, Virtuani L. Seasonal power fluctuations of amorphous silicon thin-film solar modules: distinguishing between different contributions. Progr Photovolt: Res Appl 2012:208-17.
[97] Luczak K, Grzesiak W. Energy efficient annealing of amorphous silicon modules at lower temperature. Proceedings of the 22nd European photovoltaic solar energy conference. 2007. p. 2068-71.

[98] Fanni L, Pola I, Bura E, Friesen T, Chianese D. Investigation of annealing and degradation effects on a-Si PV modules in real operating conditions. Proceedings of the 24th European photovoltaic solar energy conference. 2009. p. 3596-9.

[99] Nikolaeva-Dimitrova M, Kenny RP, Dunlop ED, Pravettoni M. Seasonal variations on energy yield of a-Si, hybrid and crystalline Si PV modules. Progr Photovolt: Res Appl 2010;18:311-20.

[100] Gopttschalg R, Betts TR, Infield DG, Keamey MJ. The effect of spectral variations on the performance parameters of single and double junction amorphous silicon solar cells. Sol Energy Mater Sol Cells 2005;85:415-28.

[101] Beyer HG, Saetre TO, Yordanov GH. Using broad-band irradiance data to mode] the short circuit response of aSi modules. IEEE PVSC 2013:751-3.

[102] Sirisamphanwong C, Ketjoy N, Sirisamphanwong C. The effect of average photon energy and module temperature on performance of photovoltaic modules under Thailand's climate condition. Energy Procedia 2014;56:359-66.

[103] Dirnberger D, Blackburn G, Müller B, Reise C. On the impact of solar spectral irradiance on the yield of different PV technologies. Sol Energy Mater Sol Cells $2015 ; 132: 431-42$.

[104] Schweiger M, Ulrich M, Nixdorf I, Rimmelspacher L, Jahn U, Herrmann W. Spectral analysis of various thin-film modules using high precision spectral response data and solar spectral irradiance data. EUPVSEC 2012:3284-90.

[105] Norton M, Gracia Amillo AM, Galleano R. Comparison of solar spectral irradiance using the average photon energy parameter. Sol Energy 2015;120:337-44.

[106] Martin N, Ruiz JM. A new method for the spectral characterisation of PV modules. Progr Photovolt: Res Appl 1999:299-310.

[107] Ross M, Rich G, Petacci L, Klammer.J. Improvement in reliability and energy yield prediction of thin-film Cds/CdTe PV modules. IEEE PVSC 2006:2148-51.

[108] Rus Casas C, Aguilar JD, Rodrigo P, Almonacid F, Pérez-Higueras PJ. Classification of methods for annual energy harvesting calculations of photovoltaic generators. Energy Convers Manag 2014;78:527-36.

[109] Dolara A, Leva S, Manzolini G. Comparison of different physical models for PV output prediction. Sol Energy 2015;119:83-99.

[110] Cameron CP, Boyson WE, Riley DM. Comparison of PV system performancemodel predictions with measured PV system performance. 33rd IEEE PVSC. San Diego, CA; 2008. [s.n.].

[111] Martinez-Moreno F, Muñoz J, Lorenzo E. Experimental model to estimate shading losses on PV arrays. Sol Energy Mater Sol Cells 2010:2298-303.

[112] Gueymard CA. Direct and indirect uncertainties in the prediction of tilted irradiance for solar engineering applications. Sol Energy 2009:432-44.

[113] Thevenard D, Pelland S. Estimating the uncertainty in long-term photovoltaic yield predictions. Sol Energy 2013:432-45. http://dx.doi.org/10.1016/j.solener.2011.05.006.

[114] Mullër B, Hardt L, Armbruster A, Kiefer K, Reise C. Yield predictions for photovoltaic power plants: empirical validation, recent advances and remaining uncertainties. European PVSEC. Amsterdam; 2014. [s.n.].

[115] Dierauf T, Kimber A, Hren R, Kurtz S. PV system energy performance evaluations. Solarpro; 2014. p. October/November, 22-40.

[116] Herteleer B, Cappelle J, Driesen J. Quantifiying low-light behaviour of photovoltaic modules by identifying their irradiance-dependent efficiency from data sheets. 27th EUPVSEC. 2012. p. 3714-9. DOI: http://dx.doi.org/10.4229/ 27thEUPVSEC.2012-4BV.4.54. [s.l.].

[117] CECPV. California Energy Commission. 〈http://www.gosolarcalifornia.org/tools/ nshpcalculator/index.php $\rangle$.

[118] Moretón R, Lorenzo E, Muñoz J. A 500 kW PV generator I-V curve. Prog Photovolt 2013. http://dx.doi.org/10.1002/pip.2401.

[119] Moretón R, Martinez F, Lorenzo E, Muñoz J, Narvarte L. An 800 kW PV generator I-V curve. 28th European PV solar energy conference and exhibition. WIP, Paris; 2013.

[120] Martinez F, Lorenzo E, Muñoz J, Moreton R. On the testing of large PV arrays. Prog Photovolt: Res Appl 2011. http://dx.doi.org/10.1002/pip.1102.

[121] SISIFO. SISIFO. [Online] 227 2016. 〈http://www.sisifo.info/〉.

[122] Belluardo G, Ingenhoven P, Sparber W, Wagner J, Weihs P, Moser D. Nove] method for the improvement in the evaluation of outdoor performance loss rate in different PV technologies and comparison with other methods. Sol Energy 2015; 117:139-52.

[123] Kenny RP, Friensen G, Chianesse D, Bermasconi A, Dunlop ED. Energy rating of PV modules: comparison of methods and approach. 3rd World conference on photovoltaic energy conversion. Osaka; 2003. [s.n.].

[124] Allet N, Baunmgartner F, Sutterlueti J, Shreier L, Pezzotti M. Haller J. Evaluation of PV system performance of five different PV module technologies. 26th European photovoltaic solar energy conference. Hamburg; 2011. [s.n.].

[125] Villalva MG, Gazloi JR, Filho ER. Comprehensive approach to modelling and simulation of photovoltaic arrays. IEE Trans Power Electron 2009, [pp. 1198208].

[126] Hoff TE, Perez R, Kleissl S, Renne D, Stein J. Reporting of irradiance modeling relative prediction errors. Prog Photo: Res Appl 2013;21:1514-9.

[127] Hegedus, Steven. Review of photovoltaic module energy yield $(\mathrm{kW} \mathrm{h} / \mathrm{kW})$ : comparison of crystalline $\mathrm{Si}$ and thin film technologies. Wiley interdisciplinary reviews: energy and environment, Vol. 2. 2013. p. 218-33.

[128] Zinber, Bastian, et al. Rating of annual energy yield more sensitivie to reference power than module technology. 35th IEEE photovoltaic specialists conference (PVSC'10). 2010. p. 1095-9. 